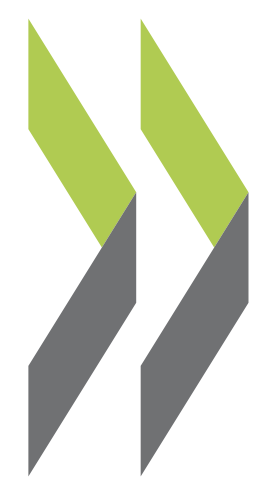

OECD Science, Technology and Industry Working Papers 2010/04

\title{
Careers of Doctorate
} Holders: Employment and

\section{Laudeline Auriol}

Mobility Patterns 
Organisation de Coopération et de Développement Économiques

Organisation for Economic Co-operation and Development

26-Mar-2010

DIRECTORATE FOR SCIENCE, TECHNOLOGY AND INDUSTRY

English text only

\section{CAREERS OF DOCTORATE HOLDERS: EMPLOYMENT AND MOBILITY PATTERNS}

STI WORKING PAPER 2010/4

Statistical Analysis of Science, Technology and Industry

By Laudeline Auriol (OECD) 


\section{STI Working Paper Series}

The Working Paper series of the OECD Directorate for Science, Technology and Industry is designed to make available to a wider readership selected studies prepared by staff in the Directorate or by outside consultants working on OECD projects. The papers included in the series cover a broad range of issues, of both a technical and policy-analytical nature, in the areas of work of the DSTI. The Working Papers are generally available only in their original language - English or French - with a summary in the other.

Comments on the papers are invited, and should be sent to the Directorate for Science, Technology and Industry, OECD, 2 rue André-Pascal, 75775 Paris Cedex 16, France.

The opinions expressed in these papers are the sole responsibility of the author(s) and do not necessarily reflect those of the OECD or of the governments of its member countries.

\section{www.oecd.org/sti/working-papers}

OECD/OCDE, 2010

Applications for permission to reproduce or translate all or part of this material should be made to: OECD Publications, 2 rue André-Pascal, 75775 Paris, Cedex 16, France; e-mail: rights@oecd.org 
DSTI/DOC(2010)4

\title{
CAREERS OF DOCTORATE HOLDERS: EMPLOYMENT AND MOBILITY PATTERNS
}

\author{
Laudeline Auriol, OECD
}

\begin{abstract}
This paper presents the results of the first large-scale data collection conducted in the framework of the OECD/UNESCO Institute for Statistics/Eurostat project on Careers of Doctorate Holders (CDH).

Doctorate holders represent a crucial human resource for research and innovation. While they benefit from an employment premium, doctoral graduates encounter a number of difficulties on the labour market, notably in terms of working conditions. These difficulties are to some extent linked to the changes affecting the research systems, where employment conditions have become less attractive. Women, whose presence among doctoral graduates has grown over the years, are more affected by these challenges.

The labour market of doctoral graduates is more internationalised than that of other tertiary-level graduates and the doctoral population is a highly internationally mobile one. In the European countries for which data are available, $15 \%$ to $30 \%$ of doctorate holders who are citizens of the reporting country have experienced mobility abroad during the past ten years. Migration and mobility patterns of doctoral graduates are similar to those of other tertiary level and other categories of the population with important flows towards the United States, principally from the Asian countries, and large intra-European flows, notably towards France, Germany and the United Kingdom. While a number of foreign graduates receive their doctorate in the host country, a large share (and the majority in the Western European countries for which data are available) have acquired their doctoral degree out of the host country and experienced mobility afterwards. Mobility of doctorate holders is driven by a variety of reasons that can be academic, job related as well as family and personal.
\end{abstract}




\title{
LES CARRIÈRES DES TITULAIRES DE DOCTORAT : DONNÉES D'EMPLOI ET DE MOBILITÉ
}

\author{
Laudeline Auriol, OCDE
}

\begin{abstract}
RÉSUMÉ
Ce document présente les résultats de la première collecte de données de grande échelle menée dans le cadre du projet conjoint OCDE/Institut Statistique de 1'UNESCO/Eurostat sur les Carrières des Titulaires de Doctorat (CTD).

Les titulaires de doctorat constituent une ressource capitale pour la recherche et l'innovation. Bien que bénéficiant d'un avantage en termes de taux d'emploi, les diplômés de doctorat sont confrontés à un certain nombre d'obstacles sur le marché du travail, notamment en ce qui concerne leurs conditions d'engagement. Ces difficultés sont en partie liées aux transformations affectant les systèmes de recherche, où les conditions d'emploi sont devenues moins attractives. Les femmes, dont la présence parmi les diplômés de doctorat s'est accrue au cours des années, sont davantage affectées par ces écueils.

L'internationalisation du marché du travail est plus marquée pour les diplômés de doctorat que pour les autres diplômés de l'université et la population doctorale est fortement mobile au plan international. Dans les pays européens pour lesquels les données sont disponibles, $15 \%$ à $30 \%$ des ressortissants du pays titulaires d'un doctorat ont effectué une mobilité à l'étranger au cours des dernières années. Les destinations des diplômés de doctorat migrants ou mobiles sont semblables à celles des autres diplômés de l'enseignement supérieur et des autres catégories de population, avec des flux importants vers les ÉtatsUnis, principalement en provenance des pays d'Asie, et des flux intra-européens conséquents, notamment vers l'Allemagne, la France et le Royaume-Uni. Bien qu'un certain nombre de diplômés étrangers reçoivent leur doctorat dans le pays hôte, une proportion importante (et la majorité dans les pays d'Europe de l'ouest pour lesquels les données sont disponibles) obtiennent leur diplôme de doctorat en dehors du pays. La mobilité des titulaires de doctorat est motivée par des raisons diverses qui peuvent être académiques, professionnelles aussi bien que familiales et personnelles.
\end{abstract}


DSTI/DOC(2010)4

\title{
CAREERS OF DOCTORATE HOLDERS: EMPLOYMENT AND MOBILITY PATTERNS
}

\author{
Laudeline Auriol, OECD ${ }^{1}$
}

\section{Introduction}

The last few decades have witnessed major developments in research and innovation systems, accompanied by important technological breakthroughs, as well as a massive expansion of higher education systems and the number of graduates. These changes have taken place in a context of economic globalisation, rapidly growing giant economies, such as Brazil, China or India, ageing populations in the developed economies and increasing migration flows worldwide. The expansion of research and innovation systems has mainly been driven by the enterprise sector, especially multinational and large enterprises and the expansion of the service sector, where $R \& D$ investment now grows faster than in manufacturing.

Investing in research and innovation is seen as stimulating economic growth and implies the availability of a highly qualified workforce. While there is indeed a growing demand for highly skilled personnel driven by research and innovation growth, there is also a continuous increase in the supply of graduates from higher education worldwide. The extent to which supply matches demand of highly skilled workers on the national labour markets is however difficult to assess. Despite the availability of an increasing pool of graduates, skill shortages have been raised by employers in many countries, especially in science and engineering. Furthermore, beyond the quantity of skilled employees needed on the labour markets, it is also the quality of their skills that is sometimes questioned. The absorptive capacity of the labour markets on the other hand may also be at stake since tertiary-level graduates are not completely spared from unemployment, even if they have better employment prospects than workers without higher education. It is also expected that the 2009 financial and economic crisis will further deteriorate the employment prospects of new entrants on the labour market, including tertiary graduates.

The OECD has for several years worked at improving the understanding of the labour conditions of its highly skilled and research trained human resources and has for this purpose launched a statistical project aimed at measuring the career and mobility of doctorate holders. This paper builds on previous work conducted in the framework of this Careers of Doctorate Holders (CDH) project and presents results of the first large-scale data collection carried out in 2007 on a subset of the population having earned their doctoral degrees between 1990 and 2006 (see Box 1).

\section{General trends and patterns in doctoral studies}

OECD countries have invested a lot of resources into higher education over the last decades. Alongside the massive expansion of higher education graduates, the number of doctoral graduates has

1 The author wishes to thank Sandrine Kergroach for her statistical support and inputs to the project, as well as Ester Basri and Sarah Box for their valuable comments on the various versions of this paper. 
dramatically increased. In the OECD area, some 200000 doctoral degrees were awarded in 2006 against 140000 in 1998, a 40\% increase in just eight years. This growth has however been uneven across countries. It was particularly steady in Portugal, Mexico, the Slovak Republic, Italy and the Czech Republic, less so elsewhere, and even stagnating in some large countries like Canada, France and Germany (Figure 1).

Doctoral graduates play a key role in research and innovation for several reasons. Firstly, they are specifically trained for research, even if additional training is increasingly required after their doctoral studies through the occupation of postdoctoral positions; secondly, they hold a diploma at the highest education level and as such are considered as the best qualified for the creation, implementation and diffusion of knowledge and innovation. They are nevertheless faced with a number of challenges, such as increasing competition with other graduates, both at their level or at a lesser level of education and the transformation of the research systems. Many countries have therefore recently reformed their doctoral programmes in order to facilitate the entry of new doctoral graduates on the labour market, notably by developing their skills in management, teamwork, fund rising or other so-called "soft skills" which are increasingly requested by potential employers and may be better made available through other educational programmes. This was for example the case in France with the creation of the "doctoral schools" at the beginning of the 1990s or in Finland with the development of the "graduate schools" in 1994.

Figure 1. Average annual growth of doctoral degrees - 1998-2006

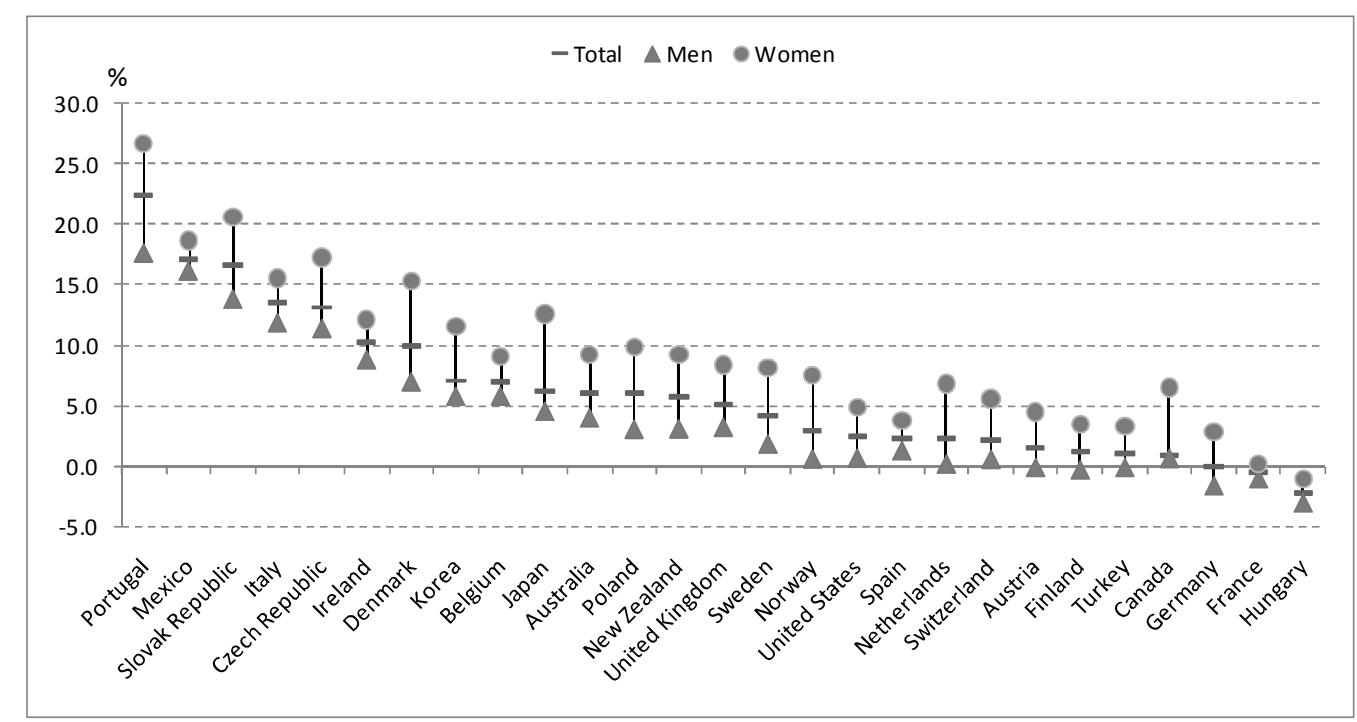

Source: OECD Education database, 2009.

The way higher education and doctoral programmes are organised is quite diverse across countries and has an impact on the age at graduation and time to completion of the doctoral degree. The data collected in the framework of the $\mathrm{CDH}$ project shows that the median age at graduation for those having received their degree between 2005 or 2006 ranges from 29 years old in Belgium to more than 39 years old in the Czech Republic (Annex Table 1). In the Nordic countries (Denmark, Finland, Iceland, Norway and Sweden), in the Baltic States and to a lesser extent in the United States, the median age at graduation is higher for women than men, which does not seem to be the case elsewhere. The median age at graduation is also higher in medical and social sciences as well as in humanities compared to science and engineering doctorates.

One explanation beyond the nature of the work involved in these disciplines, may be found in the way doctoral students are able to finance their doctoral thesis. Figure 2 shows that doctoral funding patterns 
vary across disciplines. Doctoral students in the natural and agricultural sciences, as well as in engineering can rely on teaching and research assistant posts as well as on fellowships or scholarships. Students in the medical and social sciences, as well as the humanities, on the other hand, are more dependent on other types of funding such as other types of occupations, loans or personal and family savings.

Figure 2. Percentage of graduates by primary doctoral funding source - country average, 2006
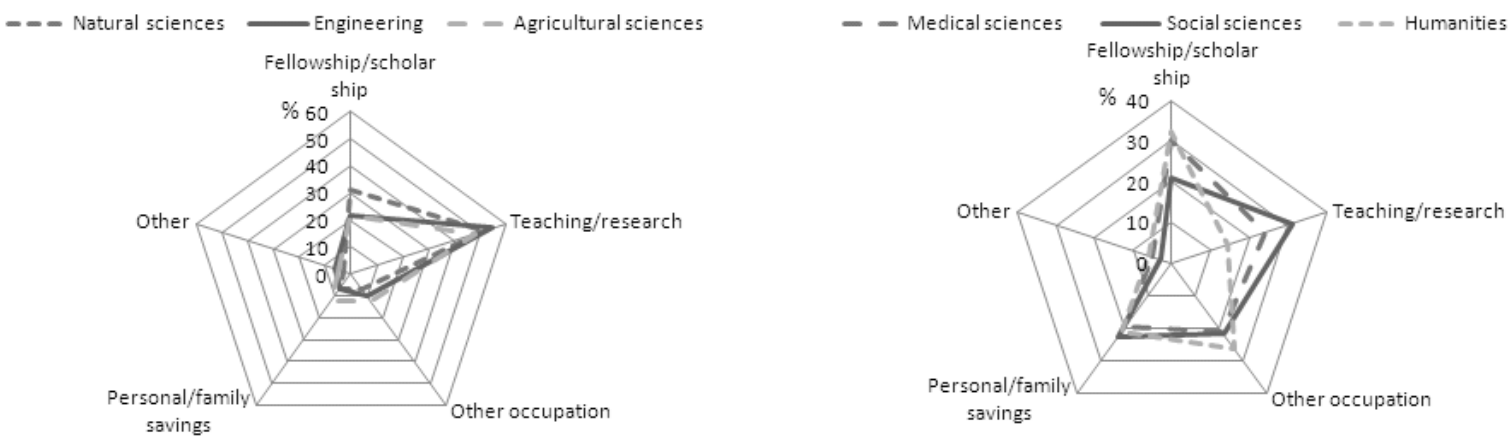

Source: OECD, 2009, OECD/UNESCO Institute for Statistics/Eurostat data collection on careers of doctorate holders.

Doctoral graduates therefore arrive late on the labour market, which in certain cases may represent a disadvantage. How many are they and in which fields do they hold their degrees?

\section{Box 1. The OECD/UNESCO Institute for Statistics/Eurostat project on Careers of Doctorate Holders (CDH)}

The Careers of Doctorate Holders (CDH) project was launched in 2004 by the OECD in co-ordination with the UNESCO Institute for Statistics and Eurostat. Its aim is to better understand the labour market, career path and mobility of a population, which is seen as being key to the production and diffusion of knowledge and innovation. The very first years of the project were devoted to developing a methodology with the help of an expert group composed of statisticians from many countries and to a first pilot data collection in 2005. Seven countries - Argentina, Australia, Canada, Germany, Portugal, Switzerland and the United States - participated and the results were presented in Auriol, 2007. This pilot exercise was also used to improve the methodology and technical components of the project methodological guidelines, core model questionnaire, instruction manual for the questionnaire and output indicators the first version of which was released in 2007 (Auriol, Felix and Fernandez-Polcuch, 2007). A second edition is currently under preparation and will soon be available.

A larger-scale data collection followed in November 2007. Some 25 countries participated and a rich set of data was made available. A number of quality and comparability limitations were however identified. In order to be able to disseminate a more coherent set of data, it was therefore decided to limit the target population to a subset common to all participating countries, i.e. doctorate holders below 70 years old having received their doctorate between 1990 and 2006. Some 20 countries ran new tabulations according to these adjustments, which resulted in an important gain in terms of data harmonisation and comparability. The new dataset is more focused on younger and more recent doctorate holders, which has an impact in terms of indicators of labour market outcome and international mobility. Unless otherwise indicated, the data presented in this paper concern this more limited subset of doctorate holders.

\section{Main characteristics of the 1990-2006 doctoral population}

In 2006, the highest numbers of 1990-2006 doctoral graduates were found in the United States (340 800) and in Germany (273 150). Figure 3 shows the percentage of this population in the total population of tertiary level graduates for 14 European countries. This percentage ranges between $1 \%$ and $3 \%$ for most Western European countries with Switzerland reaching more than 4.5\%, while it is below 1\% in the Central and Eastern European countries for which data are available. 
Figure 3. 1990-2006 doctoral graduates as a percentage of the total tertiary level population ${ }^{2}$ 2006

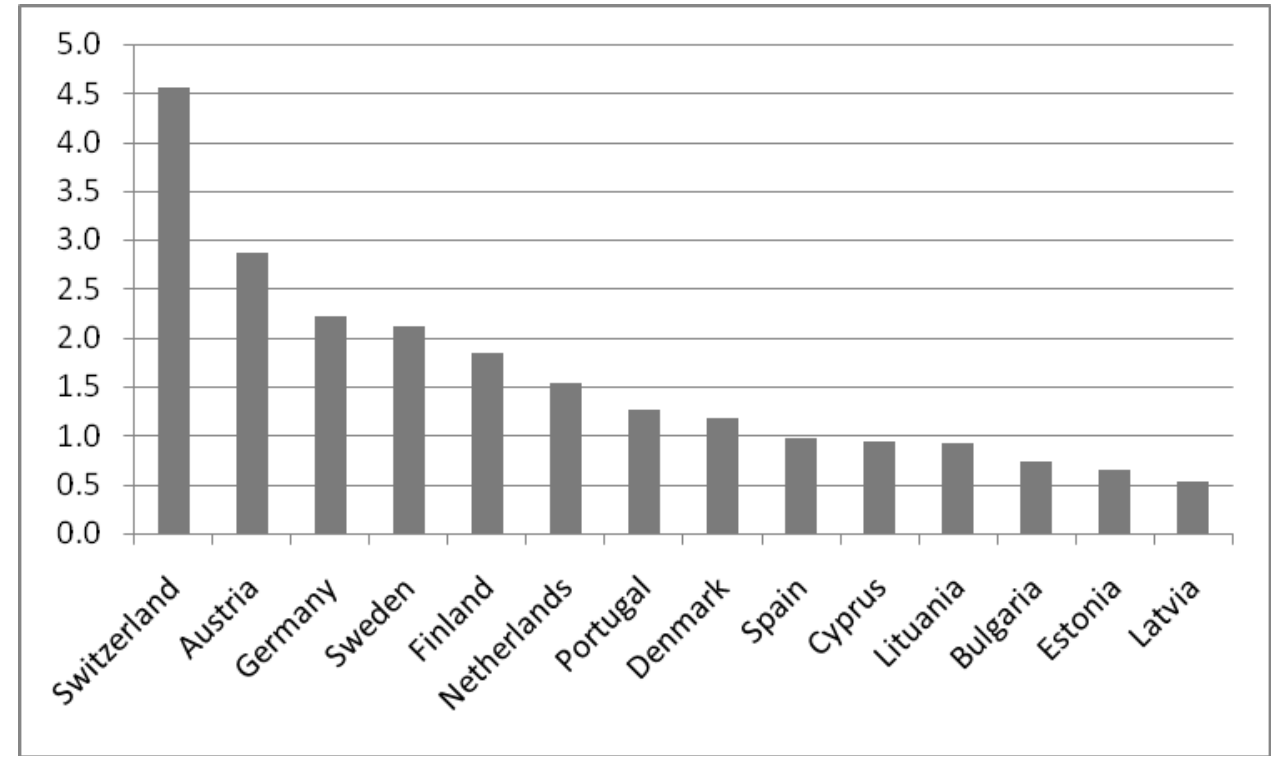

Note: $\quad$ 1987-2005 doctoral graduates for Denmark; 2005 data for Finland and the Netherlands.

Source: OECD, 2009, Eurostat and OECD/UNESCO Institute for Statistics/Eurostat data collection on careers of doctorate holders.

Due to their long education and late arrival on the labour market, the age structure of employed doctorate holders is skewed towards the upper age categories. The data available for six countries Australia, Canada, Germany, Finland, Sweden and the United States - show that the total employed population of doctoral graduates is relatively aged with a percentage of those between 55 and 64 years old representing at least one-fifth of the total employed below 65 and even one-quarter in the case of Canada, Sweden and the United States. ${ }^{3}$ These percentages are higher than for the whole population of employed tertiary graduates and also for the whole population of employed persons, which is comprised between $10 \%$ and $15 \%$, except in the case of Sweden where it is closer to $20 \%$. At the other end of the age pyramid, the share of employed doctoral graduates below 35 years old is also relatively smaller, while the shares of those in the middle-aged classes - i.e. 35 to 44 and 45 to 54 years old - are relatively more important than for the whole population of employed tertiary level graduates. Among these six countries, Germany is the only one for which the share of doctoral graduates below 45 years old reaches $50 \%$, as compared to e.g. $41.7 \%$ in the United States.

2 Footnote by Turkey: The information in this document with reference to "Cyprus" relates to the southern part of the Island. There is no single authority representing both Turkish and Greek Cypriot people on the Island. Turkey recognises the Turkish Republic of Northern Cyprus (TRNC). Until a lasting and equitable solution is found within the context of United Nations, Turkey shall preserve its position concerning the "Cyprus issue".

Footnote by all the European Union Member States of the OECD and the European Commission: The Republic of Cyprus is recognised by all members of the United Nations with the exception of Turkey. The information in this document relates to the area under the effective control of the Government of the Republic of Cyprus.

3 The data used for these six countries cover all graduation years and hence allow comparisons to be made with other graduates and categories of the population. 
To what extent should this be considered as a threat for the replacement of the cohorts of employees intending to retire? Recent OECD work (OECD, 2008a) suggests that the expansion of higher education is due to continue in the decades to come and that, with few exceptions, the demographic trends are expected to have only a moderate impact on the overall development of higher education systems. Furthermore, since 2000, doctoral awards have increased at the same pace and even slightly more rapidly than other degree awards (OECD, 2009). The steady growth of doctoral graduates can therefore be expected to continue.

Much of the increase is due to an improved participation of women. While women are still under-represented at this level of educational attainment, the composition of the doctoral population is expected to change in favour of a better balance between men and women. In 2006, the share of women with 1990-2006 doctoral degrees ranged between 30\% and 50\% in most countries for which data are available (Figure 4). Limiting the dataset to 1990-2006 graduates nevertheless confirms that they are more concentrated in the younger age classes, which indicates that they are catching up. Indeed their share among new doctoral graduates reached $45 \%$ to $55 \%$ in one-third of OECD countries in 2006 and their numbers have grown more rapidly than those of men since 1998 (Figure 1). Their distribution over fields of study however differs from that of men. Women represented only $38 \%$ on average of 2006 new science doctoral graduates (only for life science doctorates were they on a par with men) and $21 \%$ of engineering doctoral graduates.

Figure 4. Gender breakdown of 1990-2006 doctorate holders - 2006

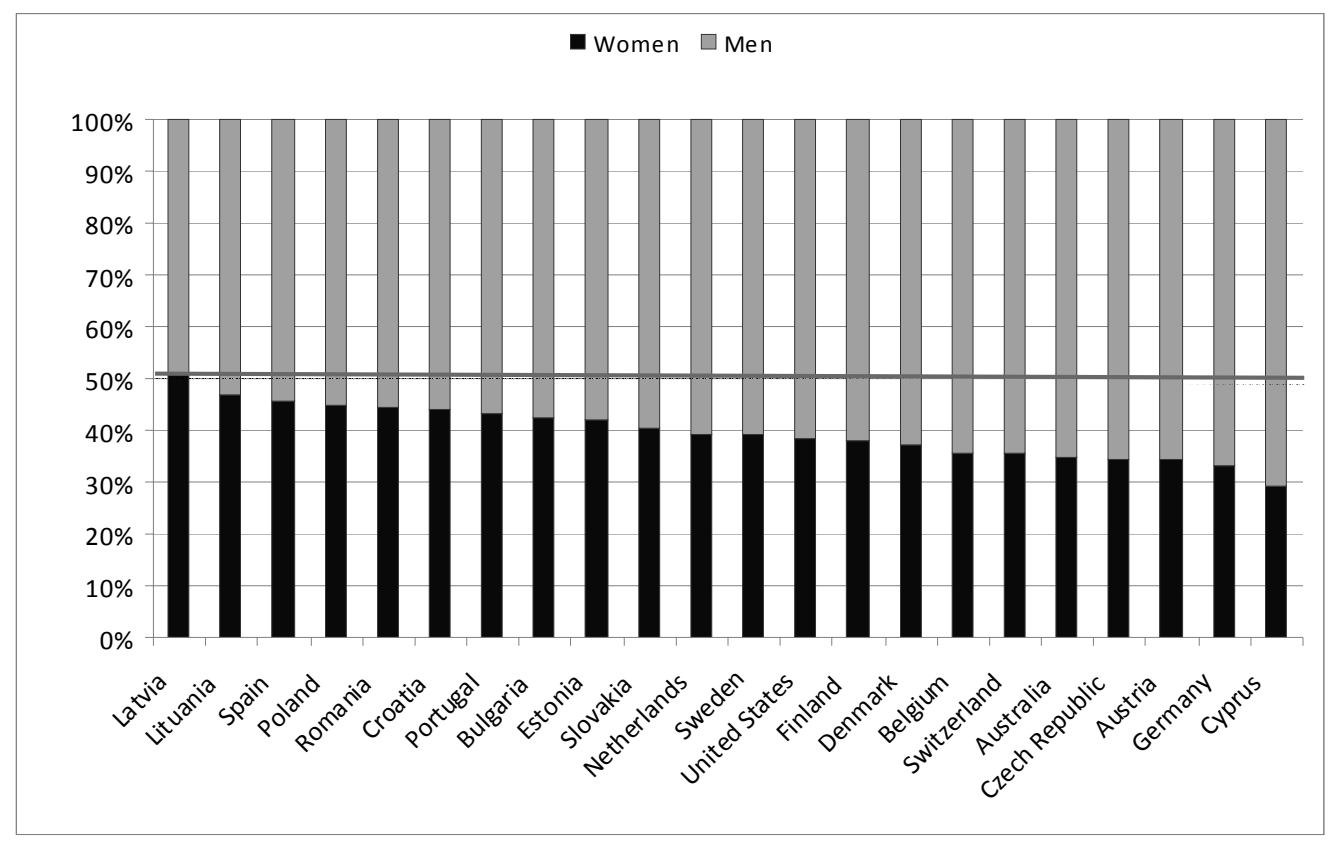

Note: $\quad$ All doctoral graduates for Australia, 1987-2005 doctoral graduates for Denmark, 2005 data for Belgium, Finland, the Netherlands and Portugal. See also Footnote 2.

Source: OECD, 2009, OECD/UNESCO Institute for Statistics/Eurostat data collection on careers of doctorate holders.

Taking both men and women together, natural sciences are the first or second major field of specialisation of doctorate holders (Figure 5). These fields represent at least $20 \%$ of doctoral graduates in all countries for which data are available and more than $35 \%$ in Denmark, Belgium and Estonia. An exception to this is Romania where only $15 \%$ graduated in these fields. 
The relative importance of others fields varies across countries. Most Central and Eastern Europe countries (Bulgaria, Czech Republic, Latvia, Lithuania, Poland, Romania, Slovak Republic) have large shares of doctorates in engineering and agricultural sciences. Graduates in engineering represent around $20 \%$ of total doctorate holders in these countries. This is also the case in Belgium, Cyprus ${ }^{4}$, and Portugal. Graduates in agricultural sciences account for more than $10 \%$ of total doctorate holders in Romania and the Slovak Republic.

Some countries on the other hand are relatively more oriented towards medical sciences. Medical sciences are the first field of doctorate award for German graduates and doctorates in this field account for $30.6 \%$. In Estonia, Denmark, Romania and Spain they represent around 20\%.

\section{Figure 5. Percentage distribution of 1990-2006 doctoral graduates over fields of degree} 2006
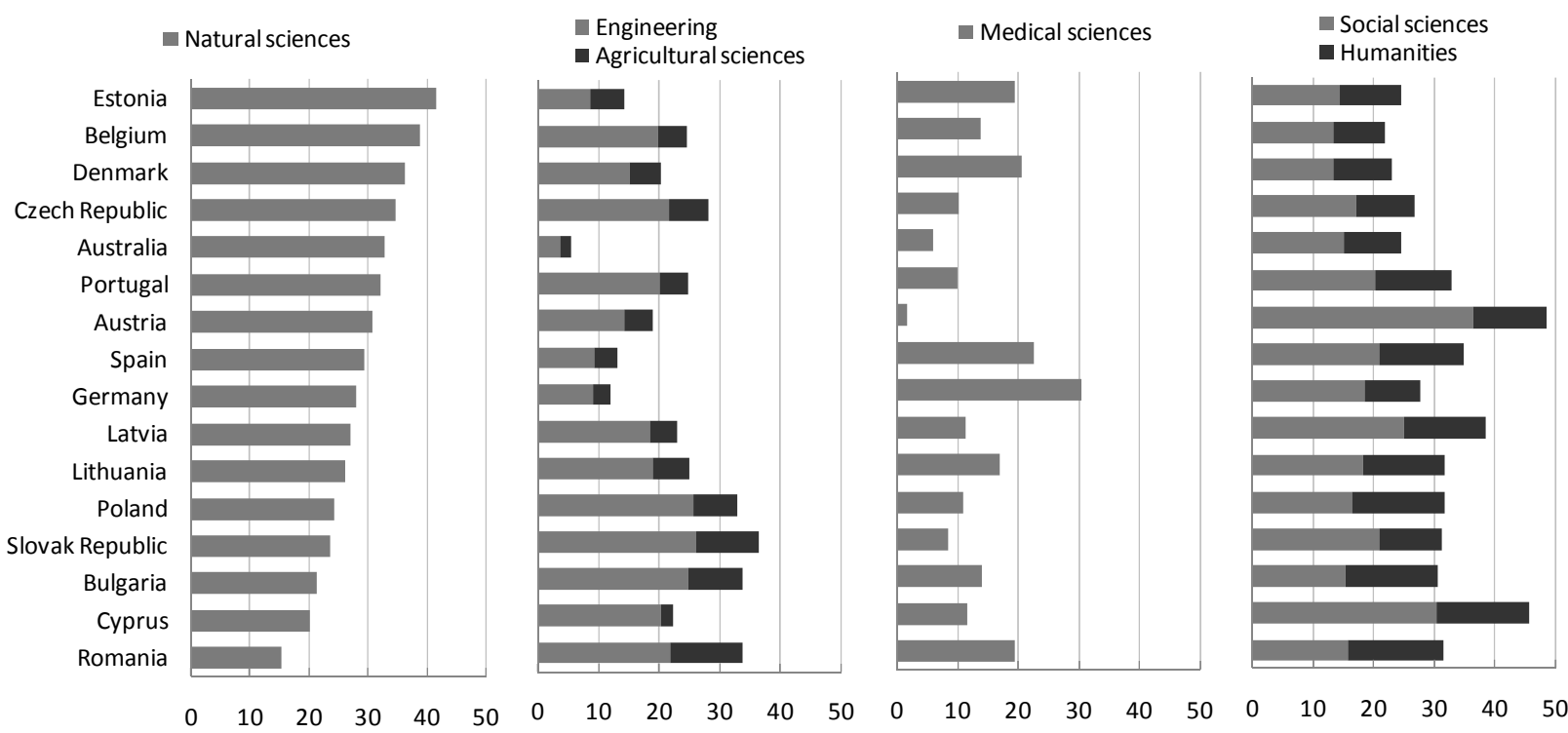

Note: $\quad$ All graduates for Australia and 1987-2005 doctoral graduates for Denmark; 2005 data for Denmark, the Netherlands and Portugal. See also Footnote 2.

Source: OECD, 2009, OECD/UNESCO Institute for Statistics/Eurostat data collection on careers of doctorate holders.

Austria and Cyprus display larger shares in the social sciences. In these two countries, social sciences are the first field of award with respectively $36.5 \%$ and $30.4 \%$ of graduates in these disciplines. Doctors in social sciences also account for $25 \%$ of doctoral graduates in Latvia and around $20 \%$ in Portugal, the Slovak Republic and Spain. For most countries, humanities represent between $10 \%$ and $15 \%$ of total doctoral degrees.

It is worth saying a word about the United States, which does not appear in Figure 4 because of the non-coverage of the humanities in the 2006 reported data. The $2003 \mathrm{CDH}$ data previously collected may however be used to estimate the share of humanities since this share seems to be rather stable over time (i.e. has not dramatically changed as compared to the one in 1993; furthermore the 2006 field distribution of the 1990-2006 graduates is also very close to that of the entire $2006 \mathrm{CDH}$ population). The estimate for the US 2006 field distribution of doctorate holders based on the 2003 share of the humanities would therefore be close to $36.5 \%$ in the natural sciences, $15 \%$ in engineering, $7.5 \%$ in the medical sciences,

$4 \quad$ See Footnote 2. 
$3 \%$ in agricultural sciences, $24 \%$ in the social sciences and $14 \%$ in humanities, showing relative high shares in both the natural sciences and the social sciences.

\section{The labour market of the 1990-2006 doctoral population}

The rapid growth of tertiary-level graduates, including at doctoral level, raises the question of the absorptive capacity of the labour market. Doctoral graduates find themselves in competition with other graduates, especially in the business enterprise sector, including in research occupations. Are doctoral graduates fully employed at their level of education, field of specialisation and as researchers?

\section{Main labour market characteristics}

First of all, it is important to acknowledge that, while differences remain between men and women (Figure 6), there is an employment premium linked to doctoral education (Figure 7). Employment rates increase with the level of education and are highest for doctoral graduates. Differences between men and women are most noticeable in Austria, Germany, the United States and Cyprus.

Unemployment rates of $1990-2006$ doctoral graduates do not exceed $2 \%$ or $3 \%$. Transition to full employment may however take some time, up to four or five years. Annex table 2 shows the higher unemployment and inactivity rates of doctoral graduates in the first years after doctoral award. The data also show that women are more likely to be unemployed and in some countries their unemployment rates are substantially higher than that of men. For example, the unemployment rate of women reaches $4.7 \%$ in Austria against $1.3 \%$ for men. Similar situations are found in Belgium (3.4\% against $2.4 \%$ ), Germany (3.9\% against $2.0 \%)$ and Spain (3.0\% against $1.1 \%)$. This may be due to several reasons, among which include their younger age as compared to men and higher share in disciplines for which unemployment is higher, like the humanities.

Unemployment rates of doctorate holders are dependent firstly on overall unemployment rates at national level and secondly, on economic cycles, in the same way as for other categories of the labour force (Figure 8). A previous $\mathrm{CDH}$ pilot data collection had revealed relatively higher unemployment rates of doctoral graduates in the natural sciences and engineering, which were probably a consequence of the economic downturn following the burst of the IT bubble (Auriol, 2007). This is less apparent in 2006, but there is still a relatively higher unemployment rate of German doctoral graduates in the natural sciences (3.8\% against $2.5 \%$ for all graduates). It is however in the humanities that unemployment rates are generally higher than in the other fields: $7.2 \%$ in Belgium, $6.2 \%$ in Denmark and $4.2 \%$ in Austria (Figure 9). The inactivity rate also reaches $11 \%$ of Austrian doctoral graduates in the humanities. With the 2009 economic downturn and the consequent rise of general unemployment, it can be expected that doctoral graduates will also be hit. 
Figure 6. 2006 employment rates of 1990-2006 doctoral graduates

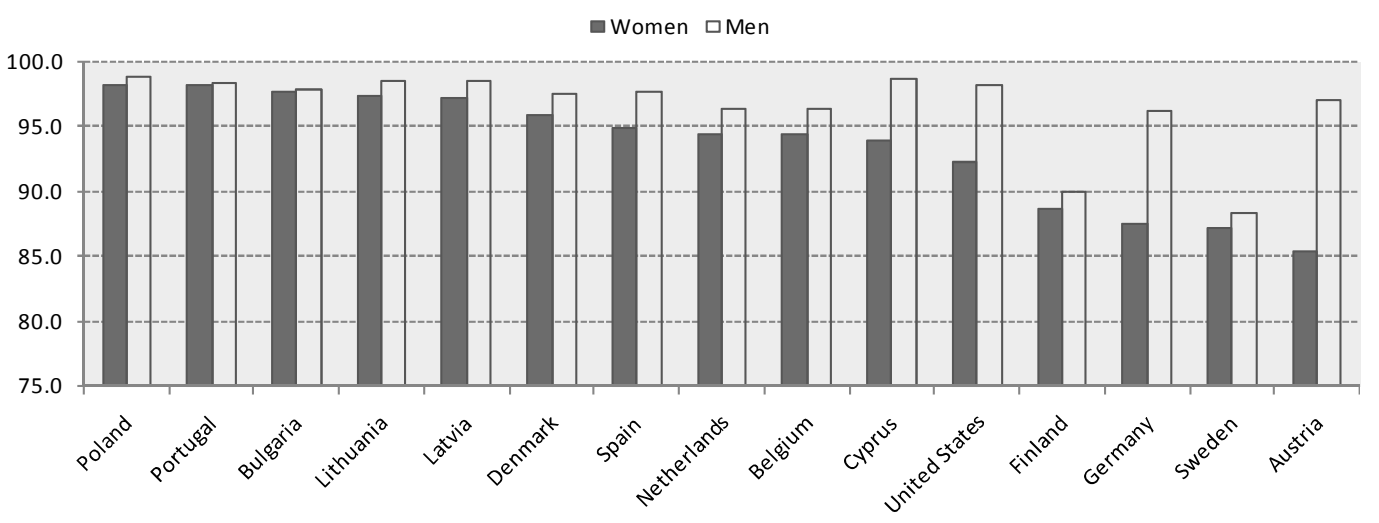

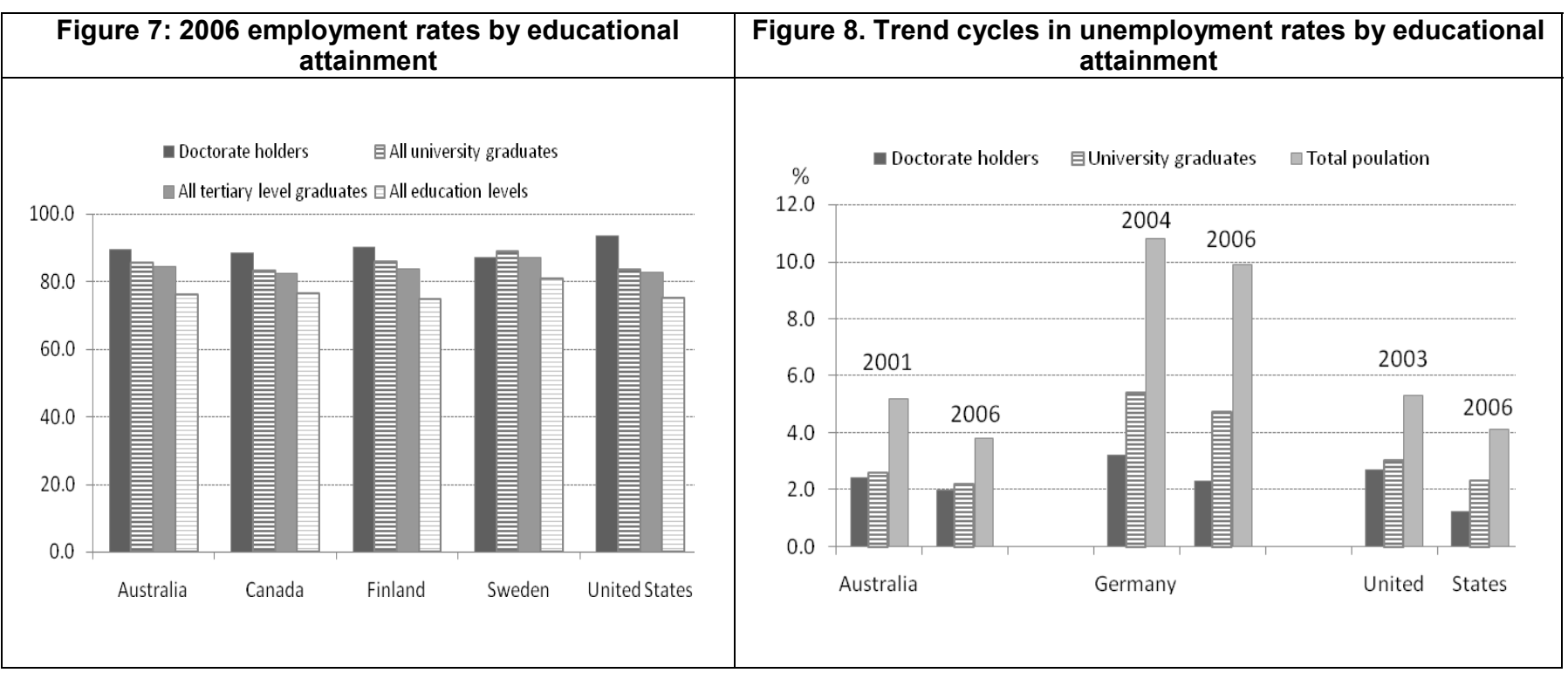

Figure 9. 2006 unemployment rates of doctorate holders by field of science

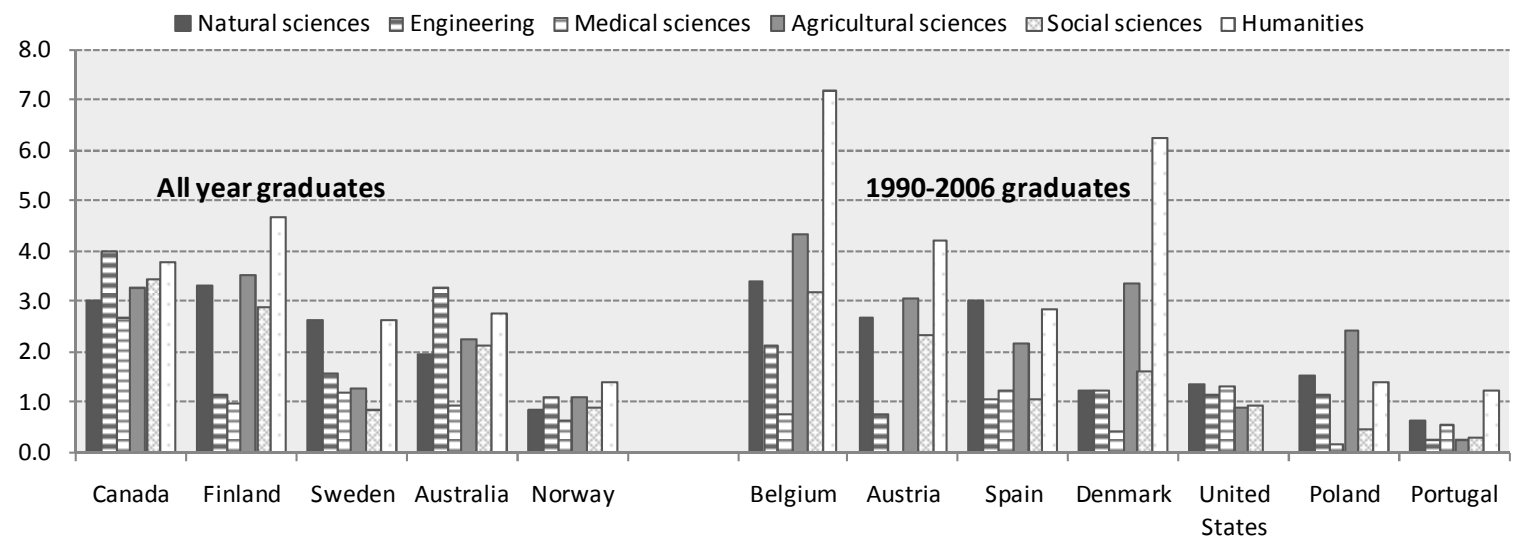

Notes: $\quad$ Employment rates are calculated as the percentage of employment on the working age population (25-64 years old); 2005 data for Belgium, Finland and Norway; 2004-2006 average for the Netherlands; 1987-2005 doctoral graduates for Denmark. See also Footnote 2.

Source: OECD, 2007 and 2009 OECD/UIS/Eurostat data collections on careers of doctorate holders; OECD Educational attainment database 2009. 
While they have better employment prospects, doctoral graduates face a number of uncertainties on the labour market. Firstly, many doctorate holders are on temporary contracts in the early stage of their careers (Figure 10). They can, in particular, be employed in postdoctoral positions for several years. ${ }^{5}$ In 2006, five years after the receipt of their doctoral degree, more than $60 \%$ in the Slovak Republic and more than $45 \%$ in Belgium, the Czech Republic, Germany and Spain were still on temporary contracts. Yet permanent engagements accounted for over $80 \%$ of all jobs in almost all countries. The incidence of temporary employment varies across disciplines. On average across countries, almost one out of four doctoral graduates is on a temporary contract in the medical sciences and the humanities against $12 \%$ in the natural sciences and $7 \%$ in engineering.

In the same way, $16 \%$ of doctorate holders in the humanities and $12 \%$ of those in the social sciences are on part-time contracts against $8 \%$ in the natural sciences and $4 \%$ in engineering. One out of ten doctoral graduates is also self-employed. The share of women on part-time or temporary contracts is also higher in all countries for which data are available. Finally, the share of foreigners on temporary employment is twice as high as that of citizens in Austria, Germany, Spain and Portugal.

Figure 10. Share of 1990-2006 doctorate holders on temporary contracts

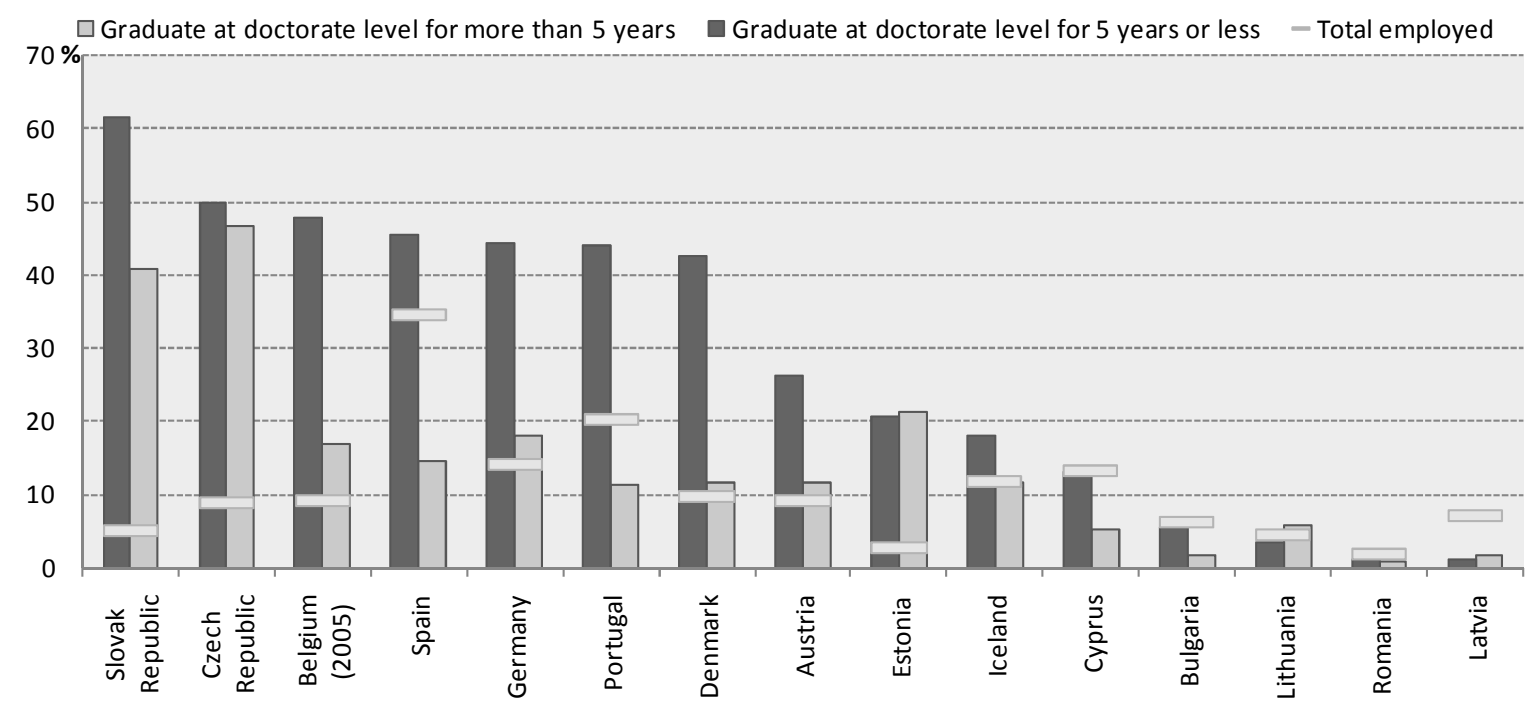

Notes: $\quad$ 1987-2005 doctoral graduates for Denmark. See also Footnote 2.

Source: OECD, 2007 and 2009 OECD/UIS/Eurostat data collections on careers of doctorate holders; OECD Employment statistics database.

5 Postdoctoral positions are here understood as temporary positions held by doctoral graduates after finalising their doctoral studies, where the main activity is research and the holder receives some kind of financial support. There are many different forms of postdoctoral positions across institutions, as well as across nations, that have made attempts to come up with an internationally agreed definition unsuccessful in the first phase of the $\mathrm{CDH}$ project. Because postdoctoral positions are so widespread, it was however deemed necessary to initiate steps to better measure them. The National Science Foundation is currently conducting a dedicated survey to better measure post-doctorates in the US. Some of the questions aimed at identifying post-doctorates in this survey have been retained for inclusion in the CDH model questionnaire. This will allow broadening the measurement of the postdoctoral phenomenon to other countries on a comparative basis. 
A non-negligible share of doctorate holders also seem to be employed in non-related or lower qualified occupations (Table 1). In 11 countries out of 20 for which data are available, one of these two indicators is at least equal to $10 \%$ and in some instances much higher, like in Austria. The doctorate holders specialised in agricultural sciences, as well as in engineering and to a lesser extent in the humanities find themselves more frequently in occupations below their qualifications. In Germany, Romania and to a lesser extent in Spain, this is more often the case for natural scientists. This may be the sign of a bottleneck or mismatch on the labour market.

Table 1. Percentage of 1990-2006 doctorate holders in a job not related to doctoral degree or below their qualification - 2006

\begin{tabular}{lcc}
\hline & & \\
& $\begin{array}{c}\text { In jobs not related to } \\
\text { their doctorate degree }\end{array}$ & $\begin{array}{c}\text { In occupations other } \\
\text { than profesional and } \\
\text { managerial (ISCO1\&2) }\end{array}$ \\
\cline { 2 - 3 } & & \\
\cline { 2 - 3 } & \% of employed doctorate holders \\
\hline Argentina & 0.9 & - \\
Austria & 29.5 & 16.4 \\
Belgium & 21.6 & 5.4 \\
Bulgaria & 6.2 & - \\
Cyprus & 12.5 & 0.3 \\
Czech Republic & 6.2 & 11.5 \\
Denmark & 14.1 & 5.1 \\
Estonia & 2.8 & 1.9 \\
Germany & - & 13.0 \\
Iceland & 7.8 & - \\
Lithuania & 7.6 & 0.4 \\
Latvia & 14.0 & 2.6 \\
Netherlands & - & 20.5 \\
Norway & 2.4 & - \\
Poland & 4.2 & 2.5 \\
Portugal & 1.2 & 1.0 \\
Romania & 5.8 & 16.1 \\
Slovak Republic & 6.6 & 11.4 \\
Spain & 17.5 & 3.8 \\
United States & 6.9 & 2.2 \\
\hline
\end{tabular}

Note:

2005 for Argentina, Belgium, Netherlands and Norway. Data for Norway relate to doctoral graduates from 2002 and 2005. See also Footnote 2.

Source: OECD, 2009 OECD/UNESCO Institute for Statistics/Eurostat data collection on careers of doctorate holders.

New data generated by the $\mathrm{CDH}$ project on satisfaction of doctorate holders with their employment situation show however that, overall, doctoral graduates are satisfied with their situation although less in terms of criteria such as salaries, benefits, job security or opportunities for advancement (Figure 11). Dissatisfaction appears more prominent in the case of women. 
Figure 11. Percentage of doctorate holders dissatisfied with their employment situation by reason of dissatisfaction (country average), 2006

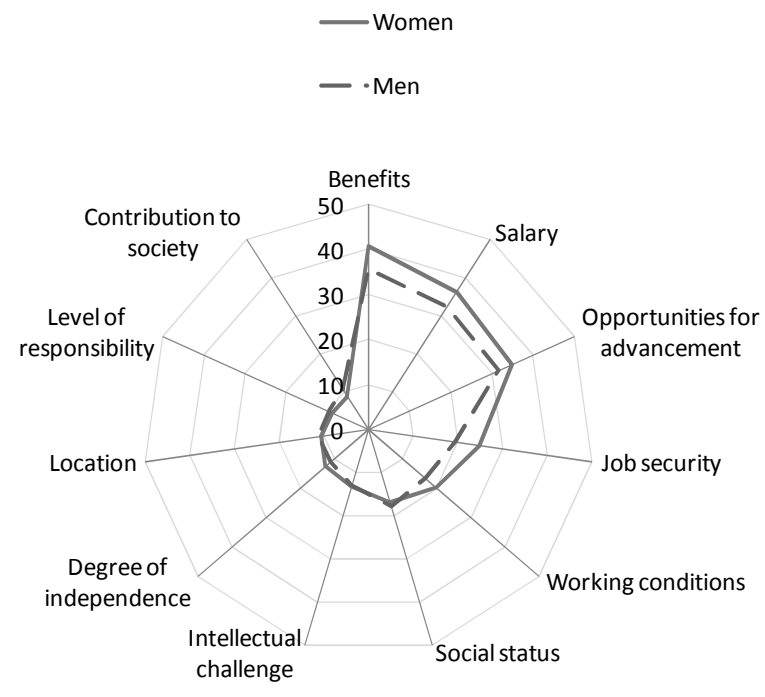

OECD, 2009 OECD/UNESCO Institute for Statistics/Eurostat data collection on careers of doctorate holders.

\section{The contribution of doctorate holders to research and innovation}

The main sector of employment for doctoral graduates is in higher education (Figure 12). The only country where this is not the case is Austria where a larger share of doctoral graduates is employed in the business enterprise sector. The business enterprise sector also employs a large share of doctorate holders in Belgium and the United States. The government sector is otherwise the second main employer of doctorate holders. While the higher education and government sectors employ doctoral graduates in all fields, the business enterprise sector targets natural scientists and engineers (Annex table 3).

Figure 12. Percentage distribution of 1990-2006 doctoral graduates by sector of employment 2006

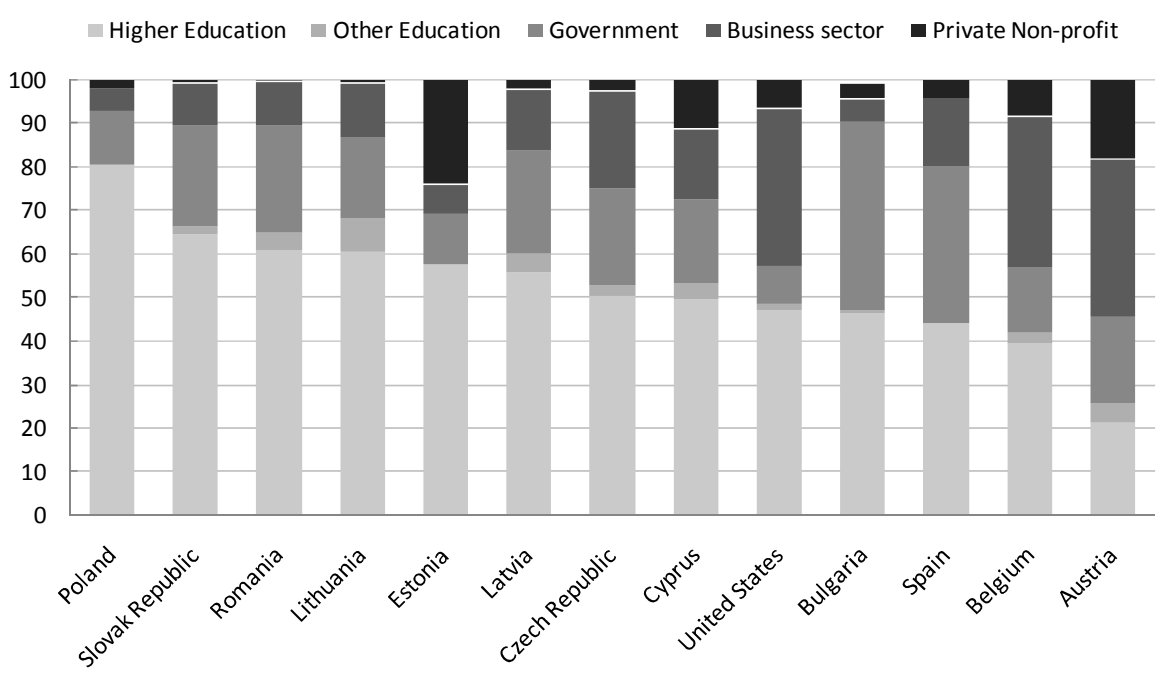

Note:

2005 for Belgium. See also Footnote 2.

Source: OECD, 2009, OECD/UNESCO Institute for Statistics/Eurostat data collection on careers of doctorate holders. 
The majority of doctorate holders also work as researchers but to an extent which varies from $50 \%$ to $80 \%$ depending on the countries. On the other hand, and in contrast to common beliefs, the majority of researchers do not hold a doctoral degree. There are exceptions in some countries, in the higher education and sometimes the government sectors. In the business enterprise sector, it is no more than $10 \%$ or $15 \%$ of researchers who hold a doctoral degree (Figure 13).

This may be explained by the different functions and organisation of the research activity prevailing in the different sectors of the economy as well as by the recent transformations of the research system. In the higher education and government sectors, the research activity is more focused on fundamental and applied research. Over recent years, the labour market of researchers in universities has also become less linear with a lower availability of tenured positions and an increase of less stable types of posts (Figure 14). In the business sector, where the research effort is more targeted to the creation of new products and production techniques, i.e. the "development" part of the R\&D activity, the skills required may be different. Enterprises employ a higher share of engineers and master degree graduates and there is higher turnover with opportunities for career development, in particular for managerial positions and outside the research function (EUA, 2009).

The CDH data show that job tenure is indeed shorter in the business sector as compared to the higher education or government sectors. Job tenure varies a lot across countries and is linked both to the age of the doctoral population and to the employment share of doctorate holders in the business sector (Figure 15).

The fact that many doctorate holders work in the higher education and government sectors, calls for a reinforcement of university-industry relationships, especially in the current economic downturn. Indeed, the consequences of the crisis will be more severe in the business enterprise sector but less so in the public sector which employs the vast majority of doctoral graduates. In this context, reinforcing universityindustry relationships would facilitate the transfer of new academic knowledge to other sectors of the economy.

The above section pointed to some dissatisfaction regarding the level of salaries. The first data collection round on the entire population of doctorate holders provided data on median gross annual earnings. The populations to which these data relate differ in terms of the coverage beyond the 1990-2006 doctoral graduates. This may affect the salary levels but probably less so the salary differentials between researchers and non-researchers or between employment sectors. The data are therefore shown here. The data reveal that in most countries for which information is available, doctoral graduates are better paid when they do not work as researchers, especially outside the enterprise sector (Figure 16). 
Figure 13. Percentage of headcount researchers with a doctoral degree $\mathbf{2} 2005$ or closest year available

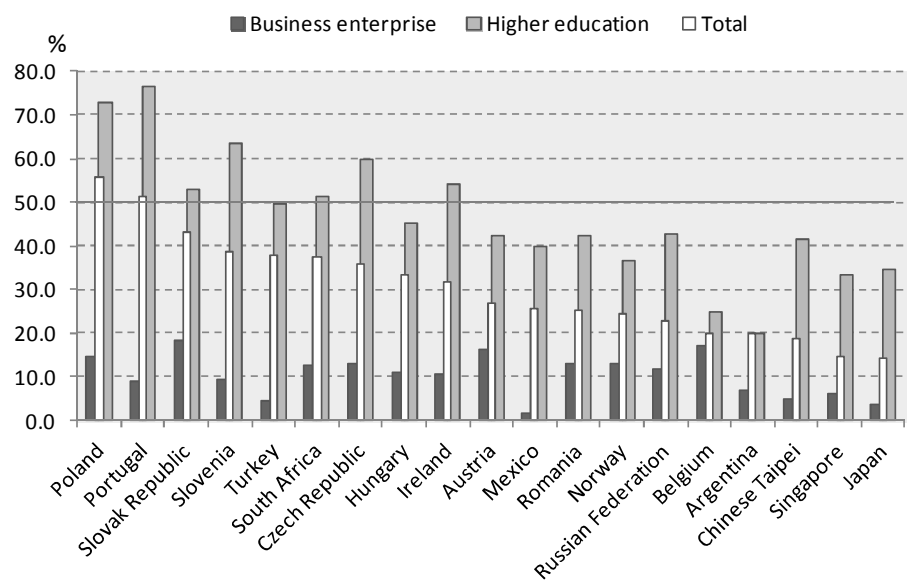

Source: $\quad$ OECD R\&D database, 2009.

Figure 14. S\&E doctorate holders with recent degrees employed at academic institutions, by type of position: United States, 1973-2006

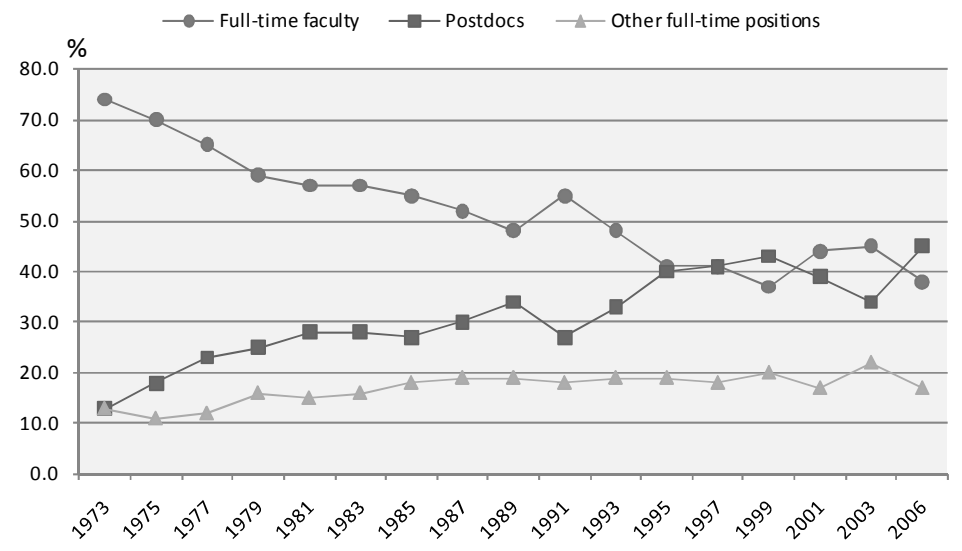

Source: National Science Foundation, Division of Science Resources Statistics, Science and Engineering Indicators 2008.

Figure 15. Link between job tenure and share of doctorate holders in the business enterprise sector

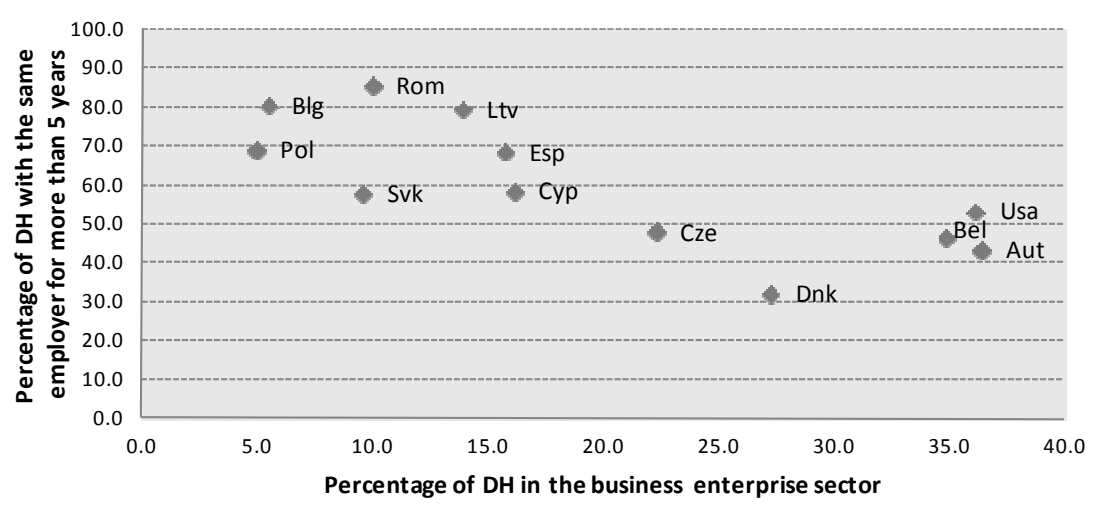

Notes: $\quad 2005$ data for Belgium; 1987-2005 doctoral graduates for Denmark. See also Footnote 2.

Source: OECD, 2007 and 2009 OECD/UIS/Eurostat data collections on careers of doctorate holders. 
Figure 16. Percentage difference in median gross annual earnings between doctorate holders working as researchers vs. those not working as researchers (2006)

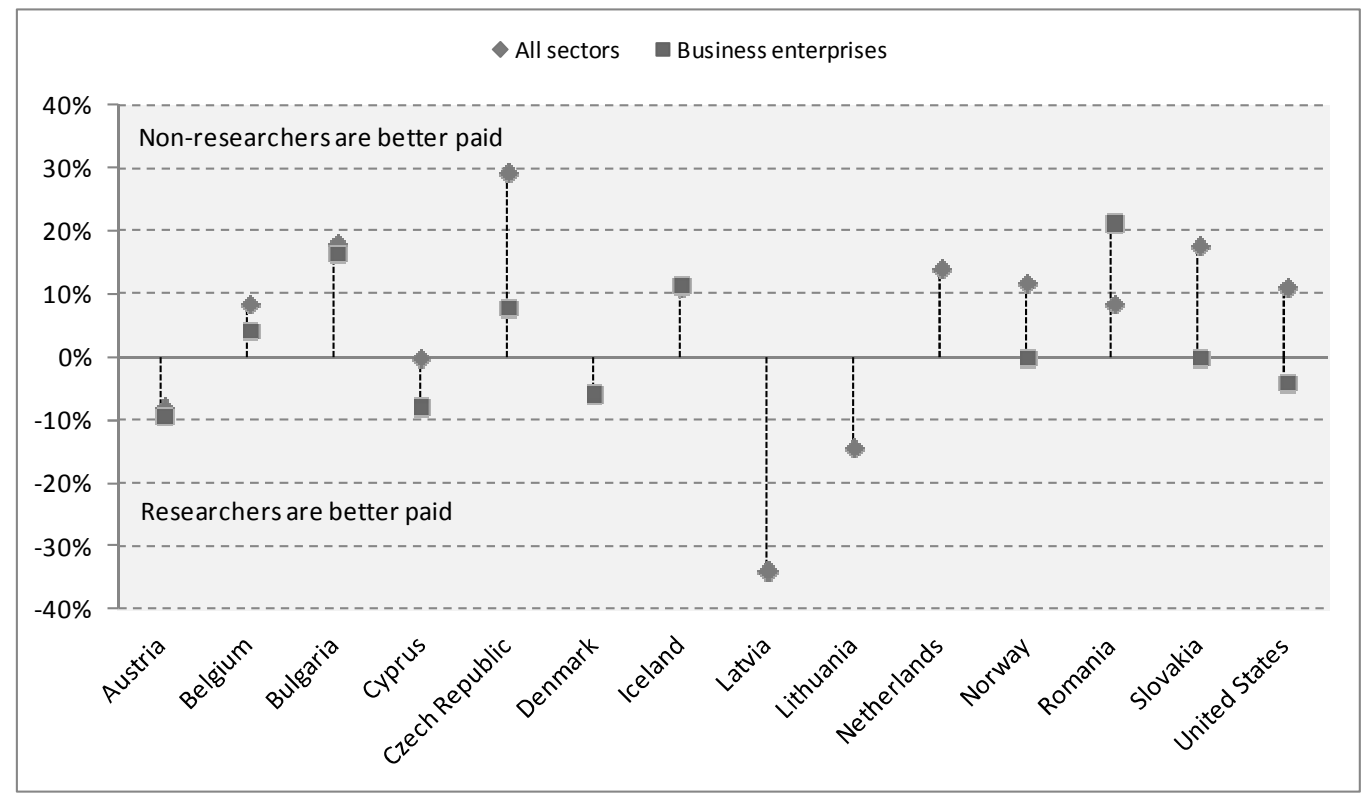

Note:

2005 for Belgium, Netherlands and Norway. See also Footnote 2.

Source: OECD, 2007 OECD/UNESCO Institute for Statistics/Eurostat data collection on careers of doctorate holders.

This could put at risk the attractiveness of research careers. With this in mind, policy makers have launched a number of actions to improve work conditions and attractiveness of research careers, such as increasing the number and amount of doctoral and post-doctoral fellowships, the salaries of young researchers, promoting access of young graduates to academic employment and improving the quality of infrastructures and the image of researchers among young people (OECD, 2006 and 2008b). In a context of increased international mobility, these measures are considered essential to maintain the supply of quality researchers and attract the best talents to the $\mathrm{R} \& \mathrm{D}$ labs.

\section{International mobility of doctoral graduates}

International exchange has always been an integral part of the research activity but has reinforced with the globalisation of the economy. A recent OECD report on the global competition of talent shows that "alongside sustained growth in foreign direct investment (FDI), in trade and in the internationalisation of research and development (R\&D), mobility of human resources in science and technology has become a central aspect of globalisation. Migration of talent now plays an important role in shaping skilled labour forces throughout the OECD area" (OECD, 2008c).

International mobility often starts at the time of researcher training since many doctoral students register in a doctoral programme abroad and therefore conduct research for their thesis in the host country. A number of them will also remain in the host country for a postdoctoral or other job position. Besides, it seems that international students are increasingly the target of large and transnational companies for their recruitment strategies (Salt, 2008).

The labour market of doctorate holders is indeed more internationalised than that of other tertiarylevel graduates: the latest round of censuses show that the share of foreign-born among doctoral graduates is higher than among other higher degree holders in most countries for which data are available (Figure 17). 
Figure 17. Share of foreign-born among doctoral and tertiary-level graduates in OECD countries, circa 2000

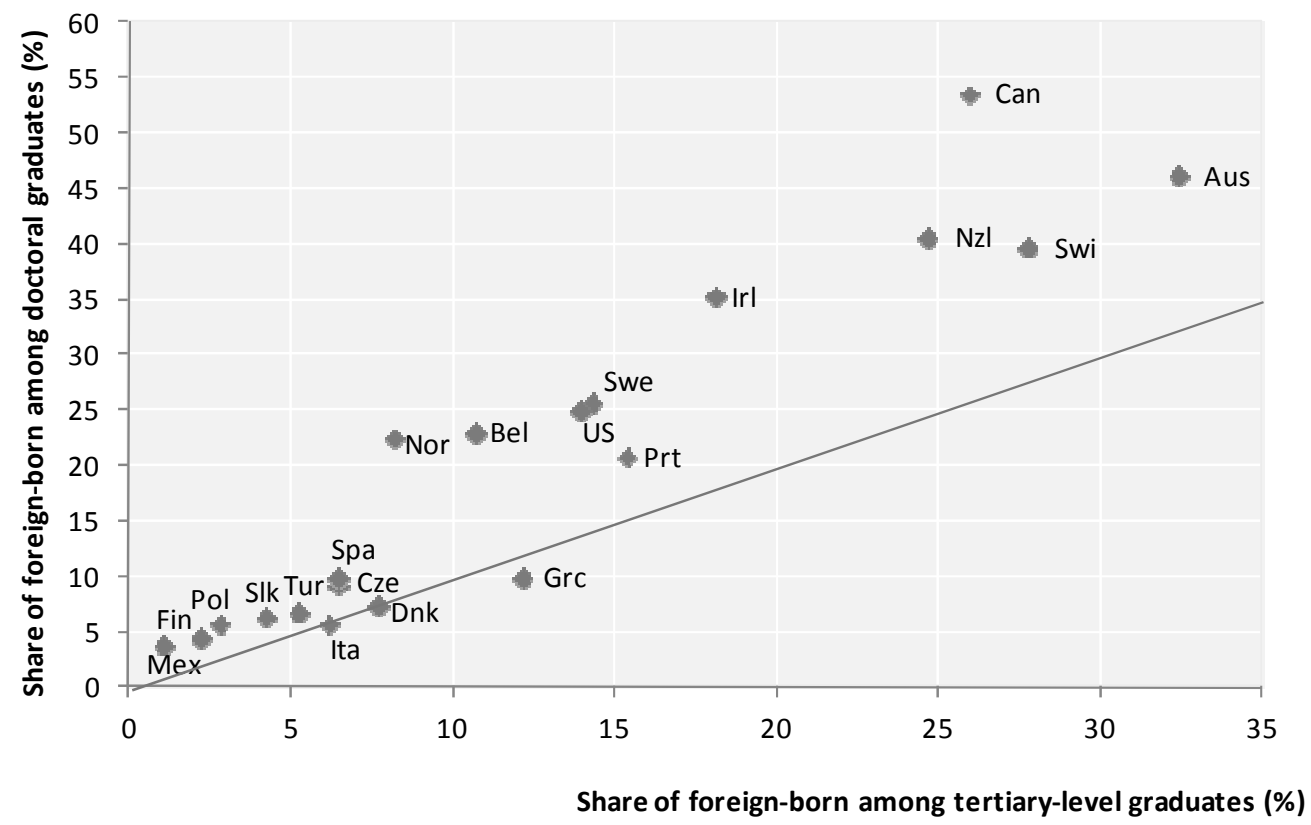

Doctorate holders are indeed a highly mobile population since a large share of them have lived abroad at the time of their education (prior or during doctoral studies) or afterwards during their professional life. In the European countries for which data are available, the $\mathrm{CDH}$ information shows that $15 \%$ to $30 \%$ of doctorate holders who are citizens of the reporting country have experienced mobility abroad during the past ten years (Figure 18). Limiting the dataset to 1990-2006 doctoral graduates slightly increases these percentages, which is a sign that mobility is more prominent among younger or more recent graduates. These percentages represent an undercount of the total mobile national citizens with doctoral degrees since they are based on the declarations of returnees. ${ }^{6}$ A non-negligible number of citizens may still be abroad with or without the intention to return. 
Figure 18. Percentage of citizens with a doctorate having lived or stayed abroad in the past ten years

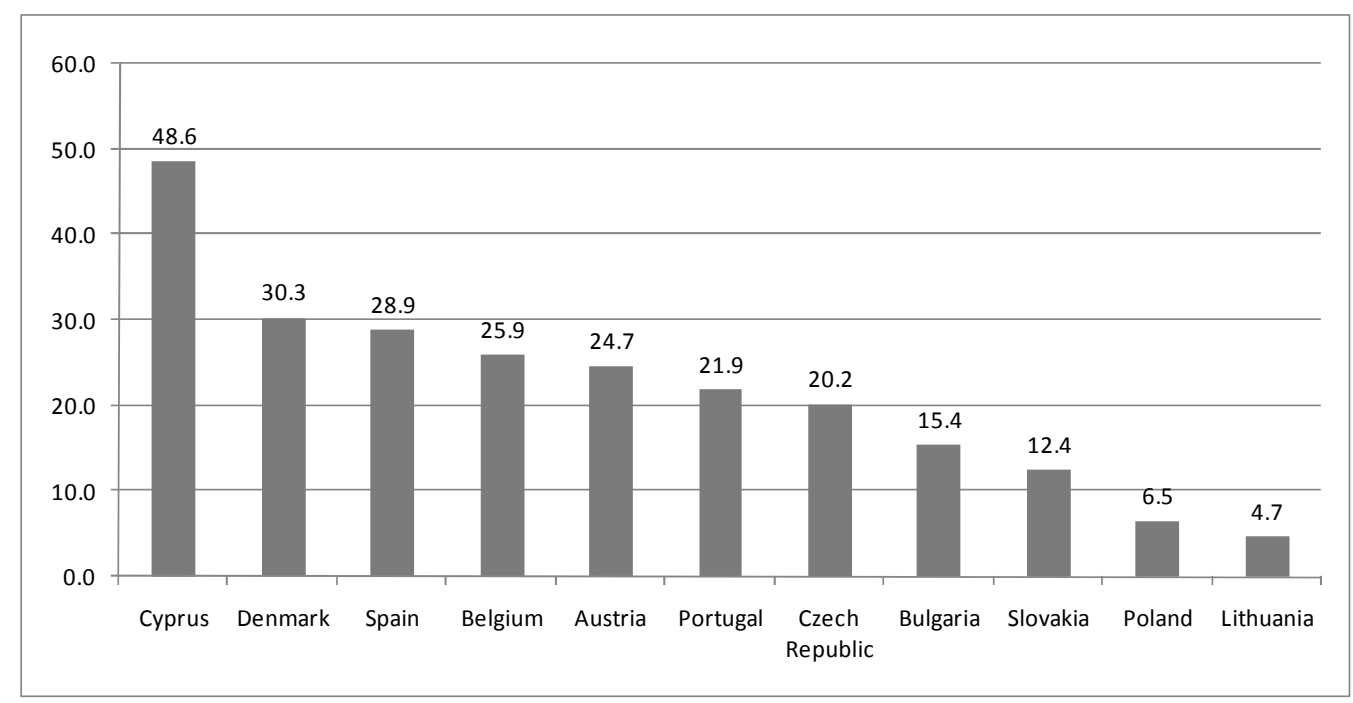

Note: 1987-2005 graduates for Denmark; 2005 data for Belgium. See also Footnote 2.

Source: $\quad$ OECD, 2009, OECD/UNESCO Institute for Statistics/Eurostat data collection on careers of doctorate holders.

Intra-European flows dominate mobility in the European countries, representing in the countries for which data are available $60 \%$ to $75 \%$ of the total movements (Figure 19). Denmark stands as an exception to this with however $47 \%$ of its doctoral citizens having experienced mobility elsewhere in Europe. While intra-European mobility dominates, the United States is one of the three main destination countries for doctorate holders from all countries (Annex table 4). The three large European countries (France, Germany and the United Kingdom) come next among the top destination countries cited. Destination choices also reflect linguistic preferences as well as geographical proximity or cultural and historical links, as in the case of other migration flows.

Figure 19. Regional destination of citizens with a doctorate having lived or stayed abroad between 1997 and 2006

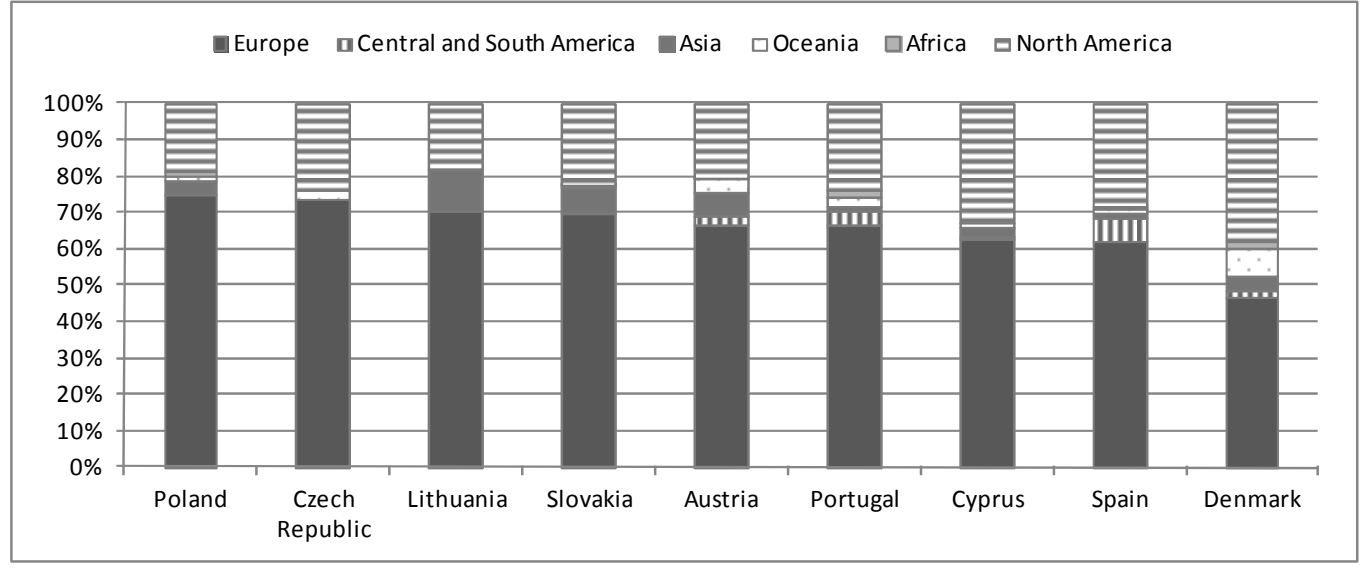

Note: $\quad$ 1987-2005 graduates for Denmark. See also Footnote 2.

Source: $\quad$ OECD, 2009, OECD/UNESCO Institute for Statistics/Eurostat data collection on careers of doctorate holders. 
Mobility to the United States, on the other hand, is dominated by doctorate holders of Asian origin, principally those of Chinese, Indian and South Korean origin. The share of Asian-born among total foreign doctoral graduates in the United States represented 51\% in 2003 while that of European-born reached 27\%. The presence of Asians is even more marked at the level of doctoral education, reaching two-thirds of foreign students.

The National Science Foundation (NSF) collects data on the intentions of newly graduated students to remain in the United States. These vary according to the origin country, but those from China and India are more likely to stay. While overall plans to stay in the United States have grown between the mid-1990s and 2007 , there are signs of a levelling off since the beginning of the decade. The 2008 version of the NSF Science and Engineering indicators publication noted that "China and India are the two major countries of origin from which the percentage of US S\&E doctorate recipients with definite plans to stay in the United States dropped from 1998-2001 to 2002-05. The drops were almost entirely among computer science doctorate recipients from India and engineering doctorate recipients from India and China." (NSF, 2008). This trend is continuing as illustrated from the latest NSF data in Figure 20.

Other evidence points to increasing returns to some of the developing countries. In the case of China and India, Jonkers stresses the combined effects of national return programmes and the improvement of broader socio-economic conditions (Jonkers, 2008). Family and personal reasons also play an important role, even in the case of a highly professionally attractive city such as Bangalore in India (Khadria, 2004). Recent OECD work confirms that return migration is strongly driven by lifestyle, family considerations and attractive employment opportunities back home (OECD, 2008c).

Figure 20. Share of foreign recipients of U.S. S\&E doctorates with definite plans to stay in the United States

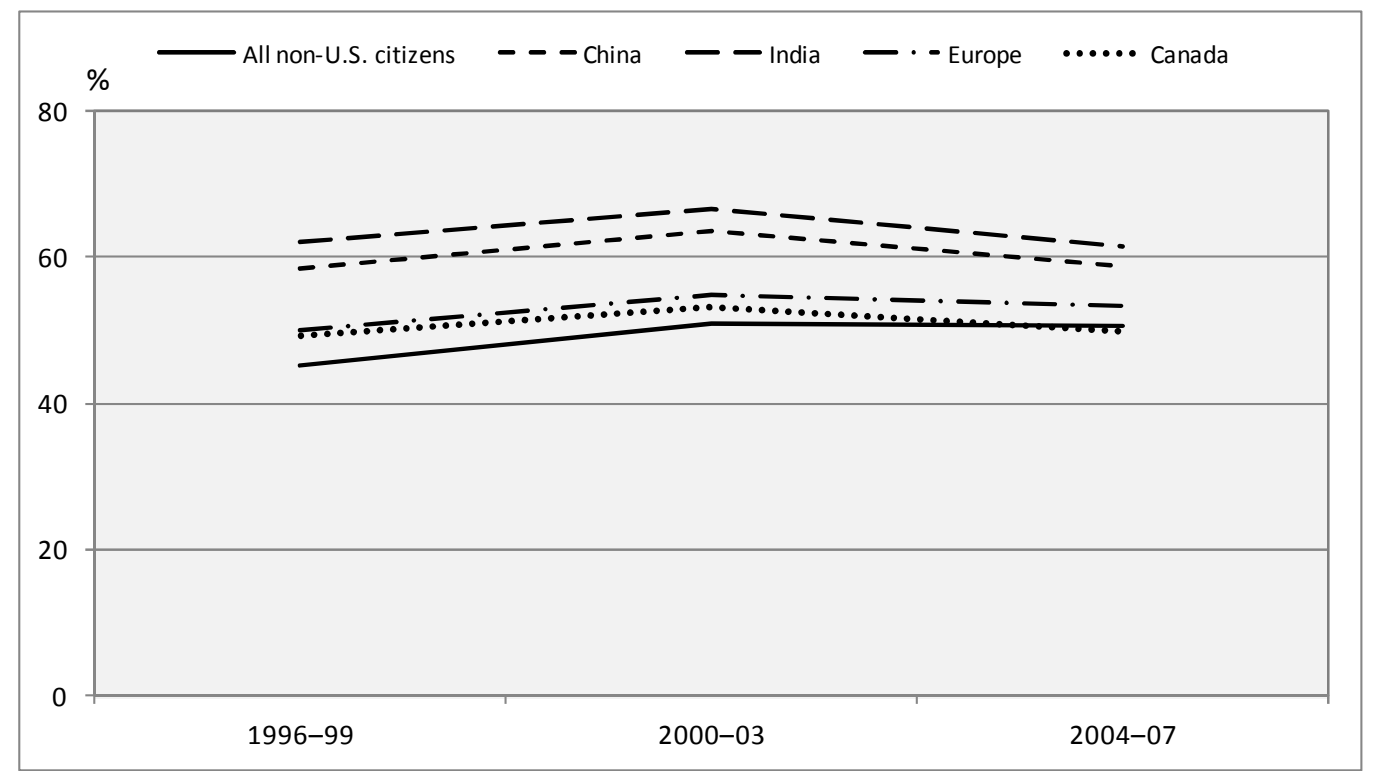

Notes: $\quad$ Data include permanent and temporary residents. China includes Hong Kong, China. Recipients with definite plans report postdoctoral research appointment or definite employment plans in United States.

Source: National Science Foundation, Division of Science Resources Statistics, Survey of Earned Doctorates, special Tabulations (2009).

While a number of foreign graduates receive their doctorate in the host country, a large share (and the majority in the Western European countries for which data are available) acquire their doctoral degree out of the host country and experience mobility afterwards. Return flows seem in any case to be increasingly 
important. The $\mathrm{CDH}$ data show that reasons given by returnees for coming back to the home country are diverse, but are in many cases personal, economic or political. Job-related reasons are also important, as well as the end of a post-doctorate abroad (Figure 21).

Figure 21. Reasons given by national citizens with a doctorate for returning to the home country

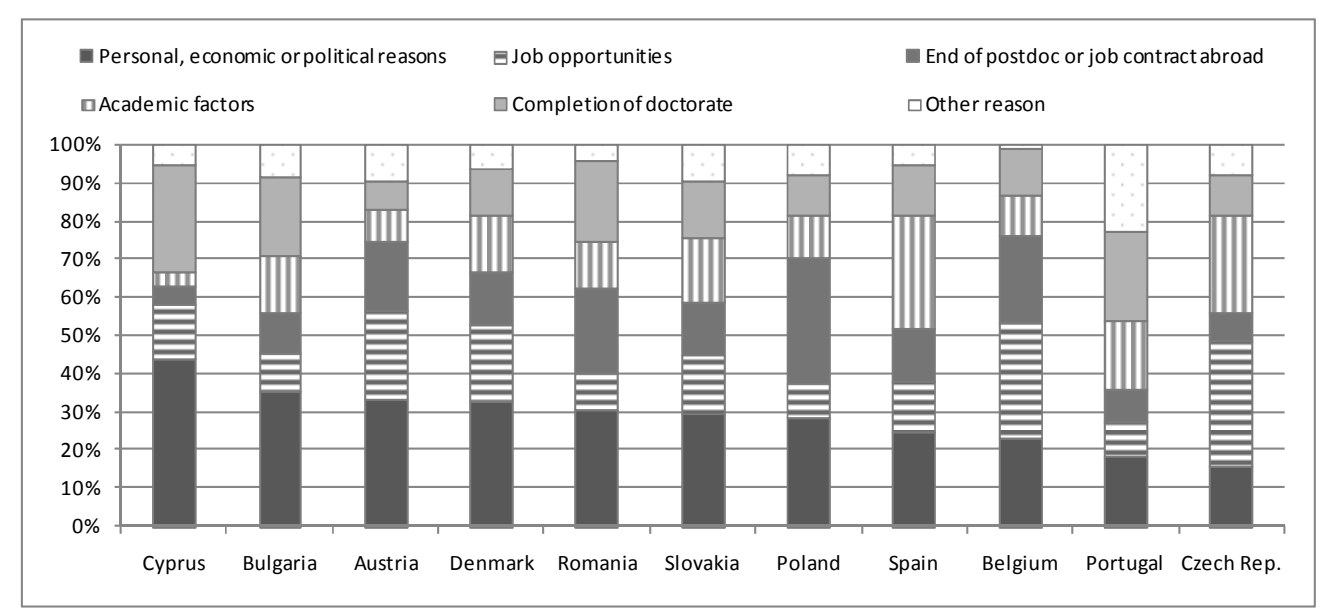

Note: $\quad$ 1987-2005 graduates for Denmark; 2005 data for Belgium. See also Footnote 2.

Source:

OECD, 2009, OECD/UNESCO Institute for Statistics/Eurostat data collection on careers of doctorate holders.

\section{Conclusions}

Recent decades have witnessed the entry of a large pool of doctoral graduates on the labour market, as well as a growing demand for highly skilled personnel and researchers. While they arrive late on the labour market and are older compared to less educated people, the steady growth of doctoral degrees and continued expansion of higher education systems will keep fuelling the labour market with new doctoral graduates in the next decades. In the more immediate future, the 2009 economic downturn may also have consequences with an increased enrolment in doctoral education due to the deterioration of the labour market for tertiary graduates.

While they benefit from an employment premium, doctoral graduates encounter a number of difficulties on the labour market, notably in terms of working conditions. These difficulties are to some extent linked to the changes affecting the research systems, where employment conditions have become less attractive. Women, whose presence among doctoral graduates has grown over the years, are more affected by these challenges. Policy measures have been implemented to limit possible adverse effects on the supply of a quality research workforce.

This is all the more important in an increasingly competitive market where doctoral graduates are highly mobile and searching for the best opportunities worldwide. New data generated by the Careers of Doctorate Holders project reveals that at least $15 \%$ to $30 \%$ of European citizens with a doctoral degree have stayed or lived abroad in the past ten years, generally in another European country. There are also important flows of Asian (especially Chinese and Indian) doctorate holders towards North America. These flows are increasingly followed by returns, including in the new emerging economies where socioeconomic conditions are improving and governments implementing return programmes. Family and personal reasons are also important in the decision to return to the home country. Mobility is seen as a main vehicle of knowledge flows by governments and supported by a wide range of policy measures. 
Strengthened and continued efforts are necessary for building indicators that can inform developments in human resource issues and help monitoring policy. This paper has shown that the new data generated by the $\mathrm{CDH}$ project serve this purpose, but there remain areas for further developments. A better measure and understanding of the volume, nature and trends of postdoctoral appointments is underway for example, as well as of the mobility between research and non-research positions or different sectors of the economy and countries. Assessing trends over time will also be ensured with the conduct of a regular and repeated data collection exercise. 


\section{REFERENCES}

Auriol (2007), "Labour Market Characteristics and International Mobility of Doctorate Holders: Results for Seven Countries", OECD Science, Technology and Industry Working Paper 2007/2, Directorate for Science, Technology and Industry, OECD, Paris, http://www.oecd.org/dataoecd/17/57/38055153.pdf.

Auriol, Felix and Fernàndez-Polcuch (2007), "Mapping Careers and Mobility of Doctorate Holders: Draft Guidelines, Model Questionnaire and Indicators - The OECD/UNESCO Institute for Statistics/Eurostat Careers of Doctorate Holders Project", OECD Science, Technology and Industry Working Paper 2007/6, Directorate for Science, Technology and Industry, OECD, Paris, http://www.oecd.org/dataoecd/6/25/39811574.pdf

EUA (European University Association) (2009), "Collaborative Doctoral Education, University-Industry Partnerships for Enhancing Knowledge Exchange", DOC-CAREERS project by Lidia BorellDamian, EUA, Brussels 2009.

Jonkers (2008), “A Comparative Study of Return Migration Policies Targeting the Highly Skilled in Four Major Sending Countries", European University Institute, San Domenico di Fiesole.

Khadria (2004), "Migration of Highly Skilled Indians: Case studies of IT and Health Professionals", STI Working Paper, 2007/2, OECD.

NSF (National Science Foundation) (2008), Science and Engineering Indicators 2008.

OECD (2006), OECD Science, Technology and Industry Outlook 2006, OECD, Paris.

OECD (2008a), Higher Education to 2030, Volume 1: Demography, OECD, Paris.

OECD (2008b), OECD Science, Technology and Industry Outlook 2008, OECD, Paris.

OECD (2008c), The Global Competition for Talent: Mobility of the Highly Skilled, OECD, Paris.

OECD (2009), OECD Science, Technology and Industry Scoreboard 2009.

Salt (2008), "Global Corporate Labour Markets and the International mobility of Expertise", DELSA/ELSA/MI(2008)3 (internal working document). 
DSTI/DOC(2010)4

ANNEX TABLES 
Table 1. Median age at graduation of recent doctoral graduates

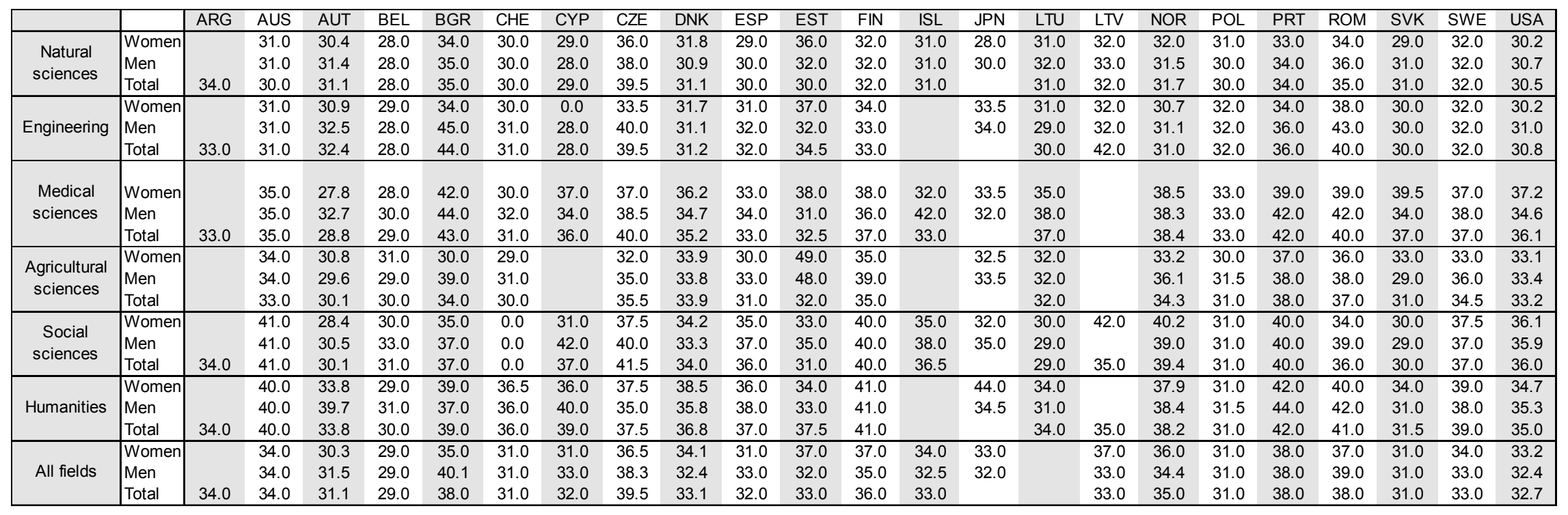

Note: $\quad$ Recent doctoral graduates are those having received their doctoral degree between 1 January 2005 and 1 December 2006; 2005 data for Argentina, Belgium, Denmark, Finland, the Netherlands and Norway. See Also Footnote 2.

Source: OECD, 2009, OECD/UNESCO Institute for Statistics/Eurostat data collection on careers of doctorate holders. 
Table 2. 2006 unemployment and inactivity rates by year of doctoral award

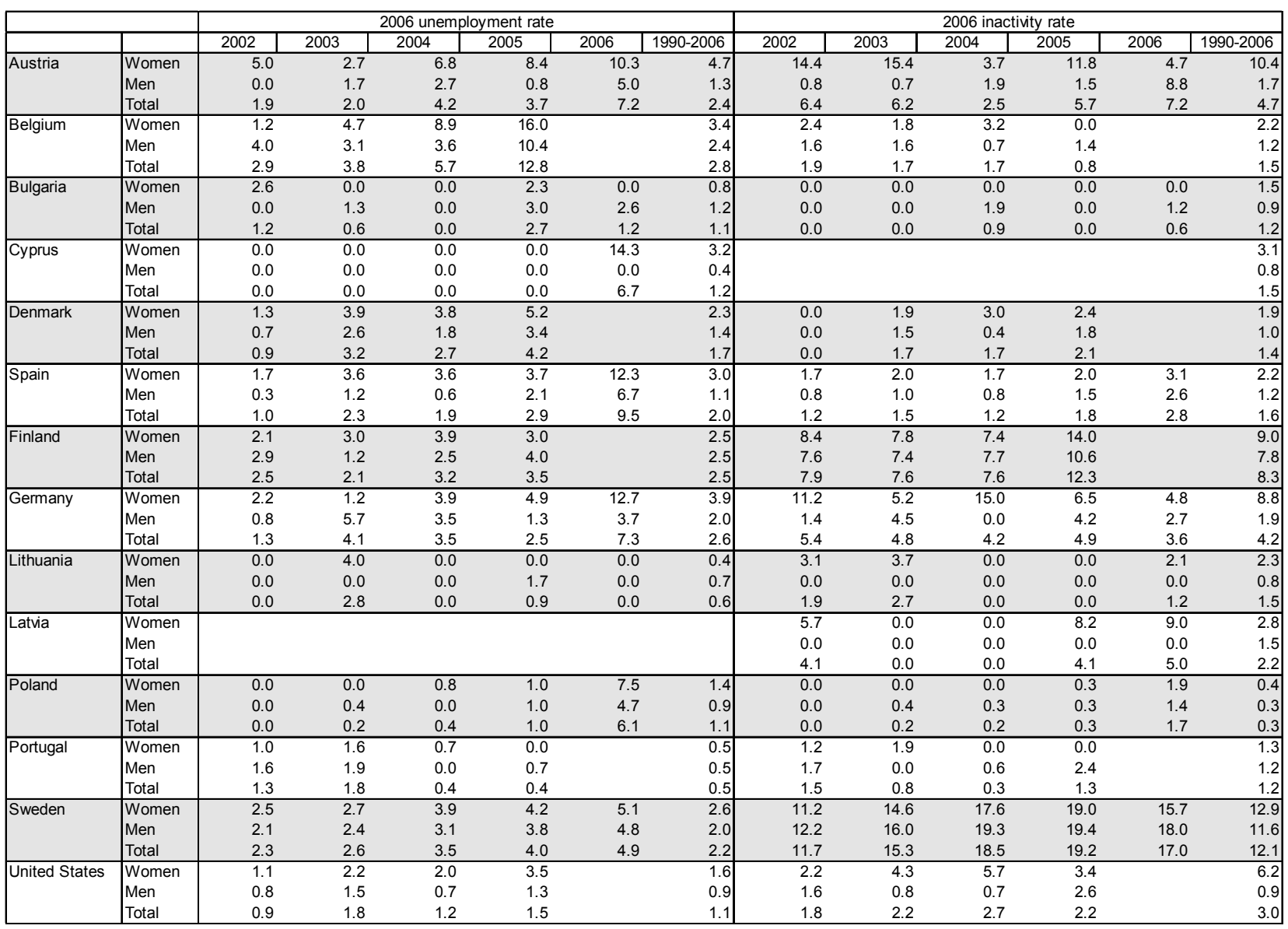

Note: $\quad$ 1987-2005 graduates for Denmark; 2005 data for Belgium, Denmark and Finland. See also Footnote 2.

Source: OECD, 2009, OECD/UNESCO Institute for Statistics/Eurostat data collection on careers of doctorate holders. 
Table 3. Percentage of 1990-2006 doctoral graduates by field of degree and sector of employment

\begin{tabular}{|c|c|c|c|c|c|c|c|c|}
\hline & & \begin{tabular}{c|} 
Natural \\
sciences
\end{tabular} & Engineering & \begin{tabular}{c|} 
Medical \\
sciences
\end{tabular} & Agriculture & $\begin{array}{c}\text { Social } \\
\text { sciences }\end{array}$ & Humanities & Total \\
\hline \multirow[t]{6}{*}{ Austria } & Business enterprise & 13.5 & 8.1 & 0.8 & 0.9 & 11.6 & 1.2 & 36.0 \\
\hline & Higher education & 8.1 & 3.0 & 0.5 & 0.9 & 6.0 & 2.9 & 21.4 \\
\hline & Government & 5.0 & 1.7 & 0.2 & 0.9 & 9.7 & 2.6 & 20.1 \\
\hline & Other education & 1.2 & 0.4 & 0.0 & 0.1 & 1.2 & 1.6 & 4.4 \\
\hline & Private non-profit & 3.1 & 1.8 & 0.2 & 1.9 & 8.2 & 2.9 & 18.1 \\
\hline & Total & 30.8 & 14.9 & 1.7 & 4.6 & 36.7 & 11.2 & 100.0 \\
\hline \multirow[t]{6}{*}{ Belgium } & Business enterprise & 17.9 & 10.7 & 2.8 & 1.1 & 1.6 & 0.4 & 34.8 \\
\hline & Higher education & 12.7 & 6.6 & 5.3 & 1.6 & 8.2 & 5.2 & 39.8 \\
\hline & Government & 5.8 & 1.7 & 2.3 & 1.4 & 1.7 & 1.8 & 14.8 \\
\hline & Other education & 1.4 & 0.2 & 0.2 & 0.0 & 0.1 & 0.4 & 2.3 \\
\hline & Private non-profit & 2.4 & 1.8 & 1.8 & 0.4 & 1.4 & 0.4 & 8.2 \\
\hline & Total & 40.3 & 21.0 & 12.4 & 4.4 & 13.1 & 8.1 & 100.0 \\
\hline \multirow[t]{6}{*}{ Bulgaria } & Business enterprise & 1.0 & 2.0 & 0.4 & 0.6 & 0.8 & 0.6 & 5.4 \\
\hline & Higher education & 6.4 & 14.2 & 6.5 & 1.9 & 8.0 & 9.7 & 46.6 \\
\hline & Government & 13.5 & 7.5 & 6.8 & 6.5 & 4.9 & 3.7 & 43.0 \\
\hline & Other education & 0.1 & 0.2 & 0.0 & 0.0 & 0.1 & 0.4 & 0.8 \\
\hline & Private non-profit & 0.2 & 0.6 & 0.5 & 0.0 & 1.2 & 0.5 & 3.1 \\
\hline & Total & 21.5 & 24.4 & 14.2 & 9.0 & 15.4 & 15.5 & 100.0 \\
\hline \multirow[t]{6}{*}{ Cyprus } & Business enterprise & 4.1 & 6.9 & 1.6 & 0.3 & 3.2 & 0.0 & 16.1 \\
\hline & Higher education & 9.8 & 12.0 & 0.3 & 0.0 & 17.7 & 10.1 & 49.8 \\
\hline & Government & 4.1 & 1.9 & 3.5 & 1.6 & 6.0 & 1.9 & 18.9 \\
\hline & Other education & 0.9 & 0.0 & 0.0 & 0.3 & 1.3 & 1.3 & 3.8 \\
\hline & Private non-profit & 0.6 & 0.6 & 6.9 & 0.0 & 1.6 & 1.6 & 11.4 \\
\hline & Total & 19.6 & 21.5 & 12.3 & 2.2 & 29.7 & 14.8 & 100.0 \\
\hline \multirow[t]{6}{*}{ Czech Republic } & Business enterprise & 6.7 & 9.5 & 0.6 & 1.5 & 3.3 & 0.4 & 22.0 \\
\hline & Higher education & 17.0 & 8.6 & 5.8 & 2.4 & 10.3 & 6.4 & 50.7 \\
\hline & Government & 9.7 & 3.2 & 3.0 & 2.1 & 2.5 & 1.8 & 22.3 \\
\hline & Other education & 0.6 & 0.2 & 0.1 & 0.3 & 0.6 & 0.7 & 2.4 \\
\hline & Private non-profit & 0.7 & 0.3 & 0.7 & 0.2 & 0.3 & 0.3 & 2.6 \\
\hline & Total & 34.7 & 21.9 & 10.2 & 6.5 & 17.2 & 9.6 & 100.0 \\
\hline \multirow[t]{6}{*}{ Spain } & Business enterprise & 5.2 & 1.5 & 5.0 & $\overline{0.6}$ & 2.0 & 1.3 & 15.7 \\
\hline & Higher education & 13.9 & 5.7 & 2.5 & 1.5 & 13.7 & 7.1 & 44.4 \\
\hline & Government & 8.7 & 1.7 & 14.4 & 1.5 & 4.9 & 4.6 & 35.8 \\
\hline & Other education & 0.0 & 0.0 & 0.0 & 0.0 & 0.0 & 0.0 & 0.0 \\
\hline & Private non-profit & 1.4 & 0.4 & 1.0 & 0.1 & 0.6 & 0.5 & 4.1 \\
\hline & Total & 29.2 & 9.4 & 22.9 & 3.8 & 21.2 & 13.5 & 100.0 \\
\hline \multirow[t]{6}{*}{ Latvia } & Business enterprise & 4.7 & 4.6 & 0.8 & 1.4 & 2.1 & \begin{tabular}{c|}
0.2 \\
\end{tabular} & 13.8 \\
\hline & Higher education & 12.3 & 9.6 & 5.5 & 2.2 & 18.3 & 8.2 & 56.1 \\
\hline & Government & 9.1 & 3.0 & 4.4 & 0.8 & 2.9 & 3.5 & 23.6 \\
\hline & Other education & 0.0 & 0.0 & 0.0 & 0.0 & 0.0 & 0.0 & 0.0 \\
\hline & Private non-profit & 0.5 & 0.2 & 0.3 & 0.0 & 0.8 & 0.3 & 2.2 \\
\hline & Total & 27.8 & 18.2 & 11.5 & 4.6 & 25.2 & 12.7 & 100.0 \\
\hline \multirow[t]{6}{*}{ Lithuania } & Business enterprise & 3.7 & 4.2 & 0.9 & 1.2 & 2.2 & 0.4 & 12.6 \\
\hline & Higher education & 15.3 & 11.7 & 8.3 & 2.6 & 12.5 & 10.1 & 60.6 \\
\hline & Government & 4.1 & 1.8 & 7.5 & 1.1 & 2.3 & 1.7 & 18.4 \\
\hline & Other education & 2.9 & 0.9 & 0.4 & 1.3 & 1.1 & 1.2 & 7.7 \\
\hline & Private non-profit & 0.0 & 0.0 & 0.2 & 0.0 & 0.2 & 0.2 & 0.6 \\
\hline & Total & 26.0 & 18.6 & 17.3 & 6.2 & 18.3 & 13.6 & 100.0 \\
\hline Poland & Business enterprise & 0.9 & 2.0 & 0.7 & 0.4 & 0.6 & 0.2 & 4.8 \\
\hline & Higher education & 18.9 & 20.1 & 8.4 & 4.8 & 15.1 & 13.3 & 80.6 \\
\hline & Government & 4.0 & 3.5 & 1.4 & 1.9 & 0.7 & 1.1 & 12.7 \\
\hline & Other education & 0.0 & 0.0 & 0.0 & 0.0 & 0.0 & 0.0 & 0.0 \\
\hline & Private non-profit & 0.4 & 0.3 & 0.3 & 0.2 & 0.4 & 0.3 & 1.9 \\
\hline & Total & 24.2 & 25.9 & 10.9 & 7.2 & 16.8 & 15.0 & 100.0 \\
\hline Romania & Business enterprise & 1.5 & 3.8 & 1.1 & 2.7 & 0.4 & 0.2 & 9.8 \\
\hline & Higher education & 7.8 & 15.3 & 11.6 & 5.0 & 10.3 & 11.0 & 61.1 \\
\hline & Government & 5.2 & 2.2 & 6.6 & 3.7 & 4.4 & 2.7 & 24.8 \\
\hline & Other education & 0.7 & 0.5 & 0.1 & 0.3 & 0.5 & 1.7 & 3.8 \\
\hline & Private non-profit & 0.1 & 0.1 & 0.1 & 0.0 & 0.1 & 0.1 & 0.5 \\
\hline & Total & 15.3 & 22.0 & 19.5 & 11.7 & 15.8 & 15.7 & 100.0 \\
\hline Slovakia & Business enterprise & 2.1 & 3.9 & 0.6 & 0.8 & 1.5 & 0.7 & 9.5 \\
\hline & Higher education & 13.6 & 17.8 & 5.9 & 6.8 & 14.2 & 6.5 & 64.8 \\
\hline & Government & 7.4 & 3.9 & 1.7 & 2.8 & 4.4 & 2.9 & 23.1 \\
\hline & Other education & 0.2 & 0.4 & 0.1 & 0.1 & 0.8 & 0.2 & 1.8 \\
\hline & Private non-profit & 0.2 & 0.2 & 0.4 & 0.0 & 0.1 & 0.0 & 0.8 \\
\hline & Total & 23.6 & 26.1 & 8.6 & 10.5 & 20.9 & 10.3 & 100.0 \\
\hline United States & Business enterprise & 14.7 & 12.0 & 2.2 & 1.0 & 6.4 & & 36.3 \\
\hline & Higher education & 20.7 & 5.2 & 5.3 & 1.7 & 14.2 & & 47.1 \\
\hline & Government & 3.2 & 1.2 & 0.9 & 0.6 & 2.5 & & 8.5 \\
\hline & Other education & 0.5 & 0.1 & 0.1 & 0.0 & 1.0 & & 1.7 \\
\hline & Private non-profit & 2.6 & 0.6 & 0.8 & 0.2 & 2.3 & & 6.5 \\
\hline & Total & 41.7 & 19.1 & 9.3 & 3.4 & 26.5 & & 100.0 \\
\hline
\end{tabular}

Note: $\quad 2005$ data for Belgium. See also Footnote 2.

Source: OECD, 2009, OECD/UNESCO Institute for Statistics/Eurostat data collection on careers of doctorate holders. 
Table 4. Ten top countries of destination for mobile citizens with a doctorate between 1997 and 2006

\begin{tabular}{|c|c|c|l|l|l|l|l|l|l|}
\hline Austria & \multicolumn{2}{|l|}{ Belgium } & \multicolumn{2}{l|}{ Bulgaria } & \multicolumn{2}{l|}{ Czech Rep. } & \multicolumn{2}{l|}{ Denmark } \\
\hline 1 & US & 1 & US & 1 & Germany & 1 & US & 1 & US \\
2 & Germany & 2 & France & 2 & France & 2 & Germany & 2 & UK \\
3 & UK & 3 & UK & 3 & US & 3 & France & 3 & Germany \\
4 & France & 4 & Netherlands & 4 & Japan & 4 & UK & 4 & Australia \\
5 & Italy & 5 & Canada & 5 & UK & 5 & Austria & 5 & Sweden \\
6 & Belgium & 6 & Germany & 6 & Swizerland & 6 & Canada & 6 & Canada \\
7 & Switzerland & 7 & Switzerland & 7 & Belgium & 7 & Italy & 7 & France \\
8 & Australia & 8 & Italy & 8 & Italy & 8 & Switzerland & 8 & Italy \\
9 & Netherlands & 9 & Spain & 9 & Hungary & 9 & Belgium & 9 & Norway \\
10 & Spain & 10 & Sweden & 10 & Poland & 10 & Spain & 10 & Netherlands \\
\hline Lithuania & Poland & Portugal & Slovakia & Spain \\
\hline 1 & Germany & 1 & Germany & 1 & UK & 1 & US & 1 & US \\
2 & Sweden & 2 & US & 2 & US & 2 & Germany & 2 & UK \\
3 & US & 3 & France & 3 & France & 3 & Czech Rep. & 3 & France \\
4 & Japan & 4 & UK & 4 & Spain & 4 & France & 4 & Germany \\
5 & Korea & 5 & Belgium & 5 & Netherlands & 5 & Belgium & 5 & Italy \\
6 & Austria & 6 & Netherlands & 6 & Germany & 6 & Japan & 6 & Netherlands \\
7 & Luxembourg & 7 & Sweden & 7 & Brazil & 7 & Austria & 7 & Portugal \\
8 & Norway & 8 & Spain & 8 & Italy & 8 & Canada & 8 & Canada \\
9 & France & 9 & Italy & 9 & Belgium & 9 & UK & 9 & Belgium \\
10 & Netherlands & 10 & Czech Rep. & 10 & Timor-Leste & 10 & Denmark & 10 & Mexico \\
\hline
\end{tabular}

Note: $\quad$ 1987-2005 doctoral graduates for Denmark, 2005 data for Belgium and Denmark.

Source: OECD, 2009, OECD/UNESCO Institute for Statistics/Eurostat data collection on careers of doctorate holders. 